\title{
The Sustainability of Concrete in Sewer Tunnel-A Narrative Review of Acid Corrosion in the City of Edmonton, Canada
}

\author{
Linping $\mathrm{Wu}^{1}{ }^{1}$ Chaoshi $\mathrm{Hu}^{2}$ and Wei Victor Liu ${ }^{1, *}$ (D) \\ 1 Department of Civil and Environmental Engineering, University of Alberta, Edmonton, AB T6G 1H9, \\ Canada; linping@ualberta.ca \\ 2 Utility Planning \& Design, City of Edmonton, Edmonton, AB T5M 3B8, Canada; chu@epcor.com \\ * Correspondence: victor.liu@ualberta.ca; Tel.: +1-780-248-5649
}

Received: 14 January 2018; Accepted: 12 February 2018; Published: 14 February 2018

\begin{abstract}
This paper is intended to conduct a narrative review on the acid corrosion of sewer tunnel concrete in the City of Edmonton-an investigation on the MIC (microbially induced corrosion) mechanism and the potential control methods to improve the sustainability of concrete. Firstly, three categories of main influencing factors were identified for the rate of MIC: hydraulic parameters, environmental factors, and concrete mixture design. Secondly, it is found that the sewer tunnel design plays an essential role in the control of the MIC. Building on that, a review was conducted on eight municipal drainage design standards in consideration of the MIC, indicating a lack of design standards of the flow velocity and pipe material. Finally, an investigation was done for cement-based rehabilitating techniques and materials.
\end{abstract}

Keywords: sustainability; microbially induced corrosion; Edmonton; control methods; rehabilitation; drainage design standards

\section{Introduction}

In sewer systems, when hydrogen sulfide gas $\left(\mathrm{H}_{2} \mathrm{~S}\right)$ emitted from sewage meets condensing moisture, the process can form sulfuric acid $\left(\mathrm{H}_{2} \mathrm{SO}_{4}\right)$ that corrodes the concrete in sewer tunnel rapidly $[1,2]$. This is known as the microbially induced corrosion (MIC), which poses a severe threat to the sustainability of concrete in sewer tunnel. Acid corrosion causes a gradual loss of concrete, which significantly reduces the service life of concrete structures in sewer systems and may lead to structural failures such as collapse, threatening public safety. Costs to rehabilitate corroded sanitary sewer tunnels can be extremely high. In the United States (US) alone, it was estimated to cost around $\$ 14$ billion USD per year to rehabilitate and replace the deteriorated sewers [3]. When sanitary structures corrode, several processes coincide as a consequence of excessive chemical content (i.e., sulfate, acids, and chloride) in wastewater. Sulfate and acids react mainly with the cement hydration products, while chloride facilitates the corrosion of reinforcing steels by destroying the protective layer on steel surface [4]. Among these chemicals, sulfuric acid is particularly aggressive because of the highly expansive corrosion products [5].

Currently, concrete MIC issues have emerged throughout the sewer system in the City of Edmonton (COE), Canada. Many sewer tunnels are significantly deteriorated. For example, in Figure 1, the chamber and tunnel segment (located under the 127 street and 153 Avenue in Edmonton; constructed in 2001), was found severely deteriorated, showing peeled-off zone and exposed rebar in a walk-through inspection conducted in 2016. As a result, the lifetime of this chamber has been significantly reduced from 75-100 years to less than 20 years. In general, the lifetime of many sewer tunnels built in the 1960s and 1970s has been greatly reduced from 75-100 years to less than 50 years. 
Severe corrosion (up to $100 \mathrm{~mm}$ in depth) was even observed in sewer tunnels built in the late 1990s (e.g., Clareview Sanitary Trunk). As shown in Figure 2, up to $20 \%$ of the sanitary infrastructure was reported to present poor conditions [6]. To repair the deteriorated sewer infrastructure, the COE has been spending a significant portion of its budget on rehabilitation. In 2009, the emergency repair cost was $\$ 6.5$ million CAD. By 2015, this number had jumped to $\$ 16.8$ million CAD [7].

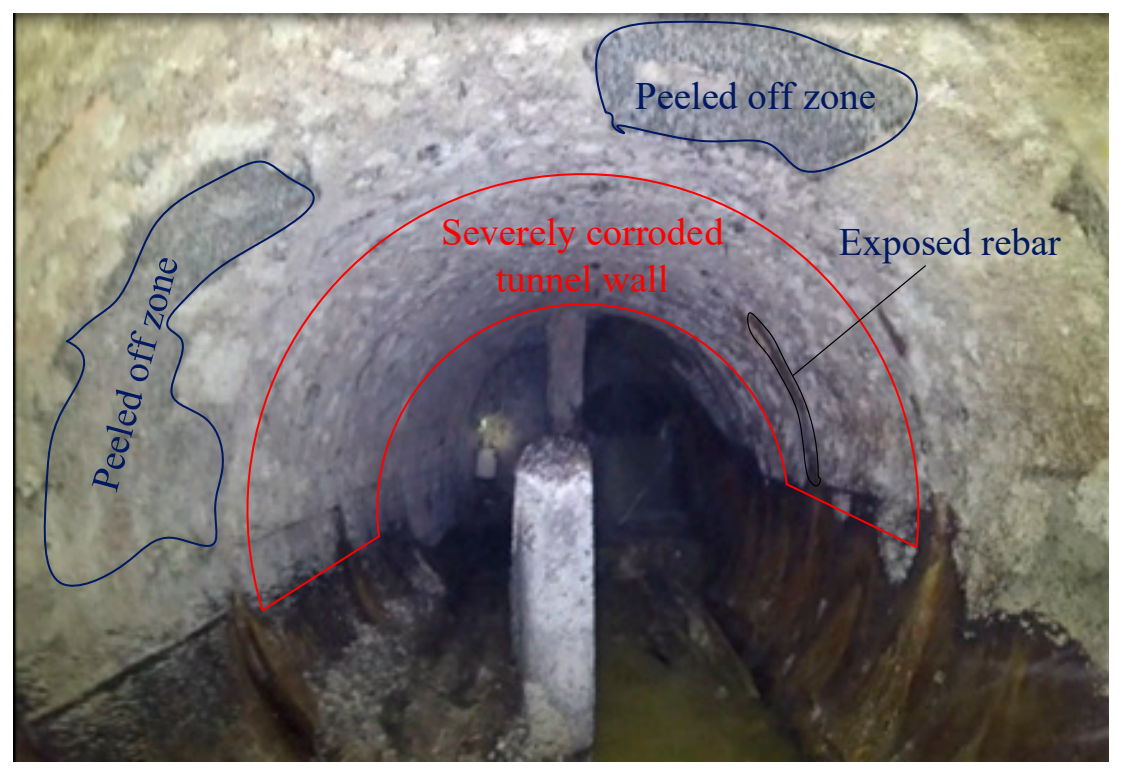

Figure 1. Corrosion conditions in a chamber located under 127 Street and 153 Avenue in Edmonton.

Theoretical Condition of Drainage Infrastructure

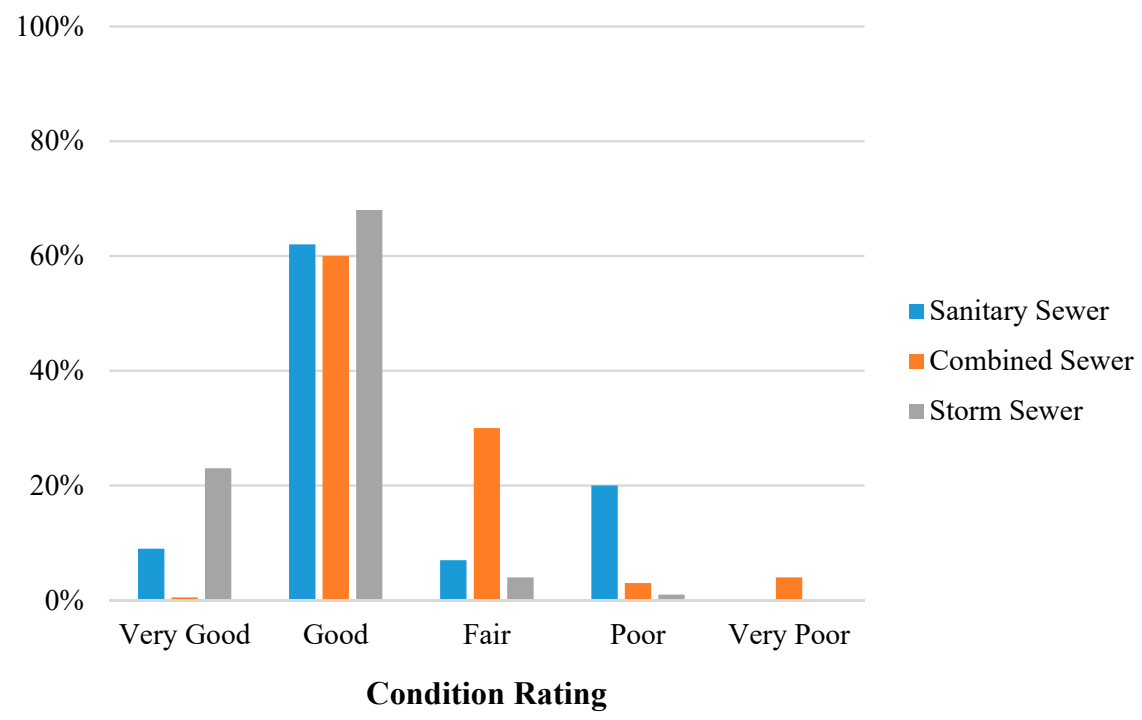

Figure 2. The estimated condition of Edmonton's drainage infrastructure [6]. Modified from "Major Edmonton sewer trunk line hanging on by 'ribs and lagging'" by E Stolte. (2015) Edmonton Journal.

However, there is a lack of understanding of how MIC occurs and what the options are to control it. To that end, this paper is intended to conduct a narrative review on the acid corrosion of sewer tunnel concrete in the COE. It aims to provide a preliminary investigation of the MIC mechanism and recommendations on how to mitigate MIC issues in Edmonton concerning drainage design, corrosion control methods, rehabilitation techniques, and materials. 


\section{Fundamentals for Microbially Induced Corrosion of Sewer Concrete}

In the sanitary sewer systems, the progress of microbially induced corrosion (MIC) often determines the service life of concrete structure [8]. Under the MIC process, aqueous $\mathrm{H}_{2} \mathrm{~S}$ is firstly converted from sulfate by bacteria activities in a slime layer. After that, the gaseous $\mathrm{H}_{2} \mathrm{~S}$ is released from sewage to the tunnel crown. This gaseous $\mathrm{H}_{2} \mathrm{~S}$ then dissolves in the moisture film formed at the tunnel crown. Finally, the dissolved $\mathrm{H}_{2} \mathrm{~S}$ is converted to sulfuric acid $\left(\mathrm{H}_{2} \mathrm{SO}_{4}\right)$ under the reactions of sulfur-oxidizing bacteria (SOB) (i.e., Thiobacillus) [9]. The sulfuric acid is the end product that reduces the $\mathrm{pH}$ value of the concrete surface down to 1-2 [10]. In such acidic environments, cement hydration products can be easily decomposed. That is, hydration products (i.e., portlandite, calcium aluminate hydrate, ettringite and calcium silica hydrate) dissolve sequentially when the $\mathrm{pH}$ of the solution gradually decreases from 12.5 to 8.8 or below [11]. In addition, the MIC is an active deterioration process in which bacteria provide sustained sulfuric acid in the reaction [10]; as a result, the MIC rate can be as high as $12 \mathrm{~mm}$ /year in many sewer systems [12] and even $14 \mathrm{~mm} /$ year in laboratory setups [13]. The following section provides more detail regarding the MIC process.

As shown in Figure 3, there are five sub-processes in MIC: carbonation, $\mathrm{H}_{2} \mathrm{~S}$ generation in sewage, $\mathrm{H}_{2} \mathrm{~S}$ buildup at the crown, sulfuric acid generation, and corrosion reaction. These sub-processes are explained in detail below.

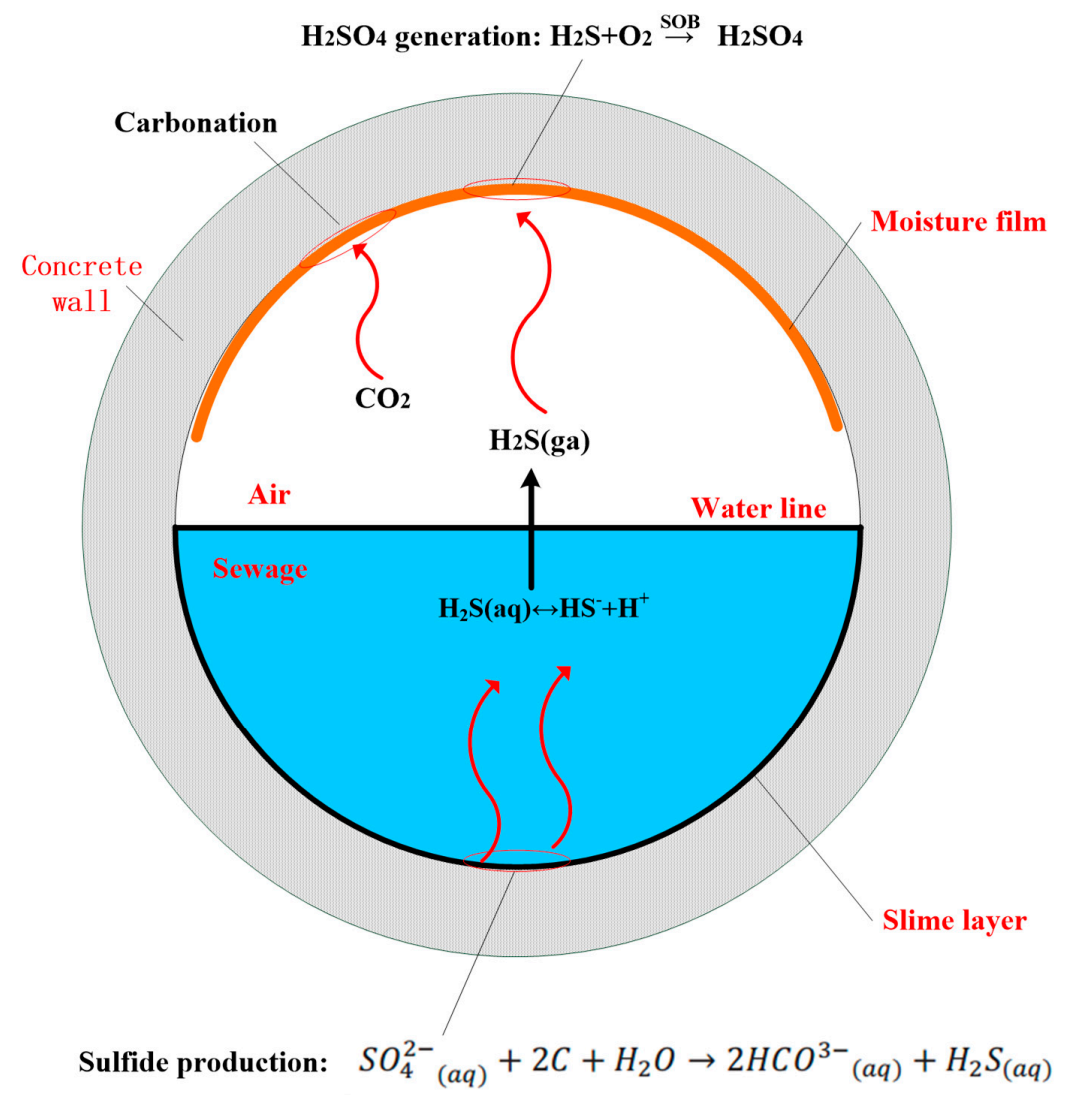

Figure 3. Schematic of the microbially induced corrosion (MIC) process within a sewer.

\subsection{Hydrogen Sulfide Generation}

The root cause of MIC is the formation of aqueous hydrogen sulfide- $-\mathrm{H}_{2} \mathrm{~S}$ (aq). It is produced from sulfate in wastewater under a reaction with sulfate-reducing bacteria (SRB) located in a slime layer. The slime layer is a layer of bacteria and inert solids at the interface between the concrete wall and the sewage- the submerged portion [14]. The slime layer is typically between 0.3 and $1.0 \mathrm{~mm}$ thick, depending on the flow velocity and solids abrasion in the sewage [15]. 
The slime layer often consists of three laminated zones (counting from the sewage toward the concrete wall): an aerobic zone, an anaerobic sulfate-reducing zone, and an inert layer. These zones are presented in Figure 4. The aerobic zone has aerobic SOB that consumes the dissolved oxygen (DO) in sewage. The other two zones consist of SRB that requires an anaerobic environment (e.g., DO level $<0.1 \mathrm{mg} / \mathrm{L}$ ). As it penetrates through the slime layer, oxygen in sewage is firstly consumed in the aerobic zone, leading to the second zone-an anaerobic sulfate-reducing zone [10]. The second zone is suitable for the growth of anaerobic SRB. In addition, as shown in Equation (1), these anaerobic $\mathrm{SRB}$ generate $\mathrm{H}_{2} \mathrm{~S}$ from the nutrients-sulfate and organic matters (org). The nutrients in sewage are gradually consumed by SRB while they diffuse through the slime layer, and nutrients concentration approaches zero near the surface of the concrete wall. At this location, the third zone, the inert layer, is formed. This portion of the slime layer is called the inert layer because it cannot receive enough sulfate and organic matter, and therefore the bacteria become inactive [15].

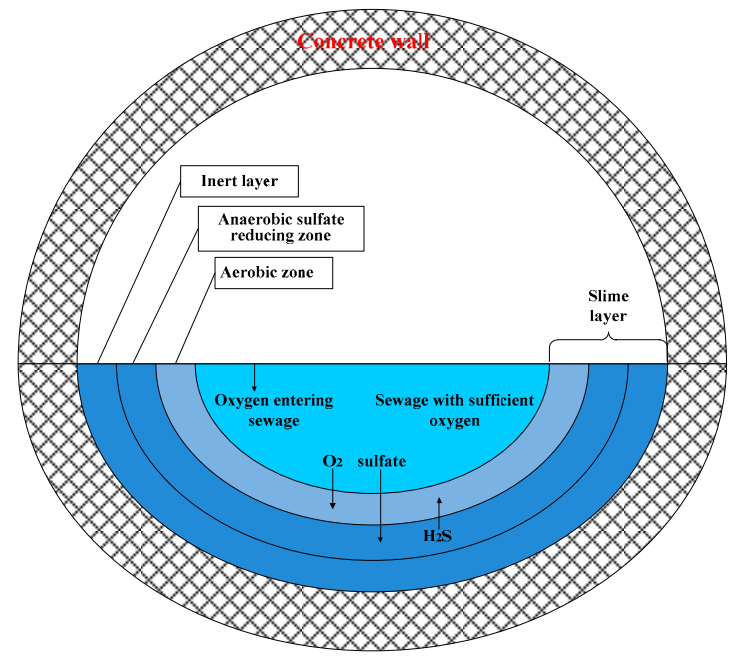

(a)

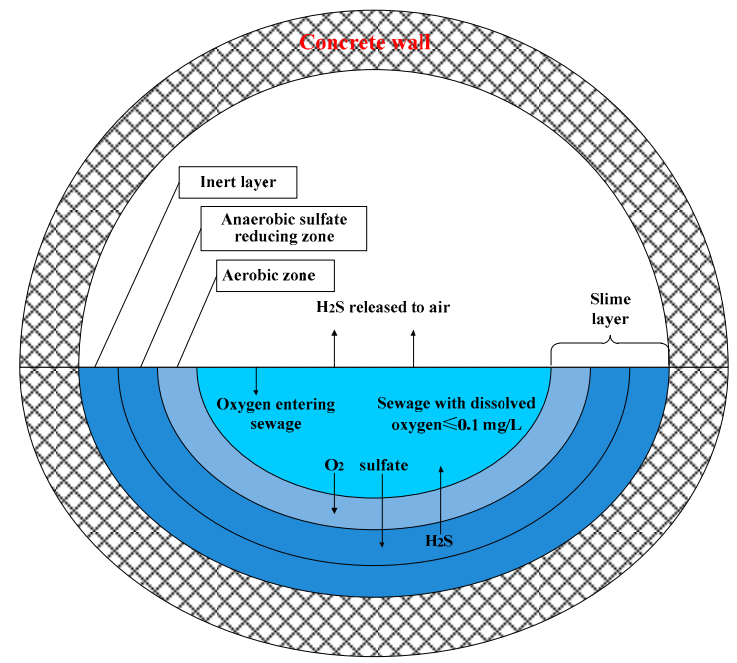

(b)

Figure 4. Process occurring in sewage with: (a) sufficient dissolved oxygen; and (b) insufficient dissolved oxygen.

The amount of $\mathrm{H}_{2} \mathrm{~S}$ that can be emitted from the slime layer is highly dependent on the DO level in sewage [10]. If the DO level is high, $\mathrm{H}_{2} \mathrm{~S}$ will be oxidized by the $\mathrm{SOB}$ in the aerobic zone-the first layer. As a result, no $\mathrm{H}_{2} \mathrm{~S}$ can escape from the slime layer to the sewage, as shown in Figure 4a. On the other hand, when the DO level in sewage is low, and DO is not enough to consume all the $\mathrm{H}_{2} \mathrm{~S}$, the $\mathrm{H}_{2} \mathrm{~S}$ (aq) can diffuse through the aerobic zone-the first layer-and then disperse in the sewage as $\mathrm{H}_{2} \mathrm{~S}$ (aq), as shown in Figure $4 b$.

$$
\mathrm{SO}_{4}^{-2}+\text { org } \rightarrow \mathrm{H}_{2} \mathrm{~S}+\mathrm{HCO}_{3}^{-}
$$

Many factors influence the concentration of dissolved $\mathrm{H}_{2} \mathrm{~S}$ in sewage, including the DO level, temperature, flow velocity, retention time, and biochemical oxygen demand (BOD). These factors are summarized in Table 1. Among these factors, the DO level is the most important $[10,16]$ because other factors mostly affect the $\mathrm{H}_{2} \mathrm{~S}$ generation by altering the DO level in sewage. For example, temperature changes the oxygen solubility in wastewater; a high flow velocity encourages the aeration of wastewater; and a long retention of sewage gradually depletes $\mathrm{DO}$ in wastewater as a result of the relatively slow dissolution of new oxygen from the tunnel atmosphere. Another important parameter is the BOD that indicates the nutrient concentration-a high BOD level means that bacteria are more active in consuming DO in sewage. 
Table 1. Summary of factors affecting $\mathrm{H}_{2} \mathrm{~S}$ generation.

\begin{tabular}{lll}
\hline Factors & Effects on $\mathbf{H}_{2} \mathrm{~S}$ Generation \\
\hline DO & $\bullet$ & $\begin{array}{l}\text { High DO enhances the oxidation of } \mathrm{H}_{2} \mathrm{~S} ; \text { thus, it reduces the release of } \mathrm{H}_{2} \mathrm{~S} \text { from the } \\
\text { slime layer. }\end{array}$ \\
\hline BOD & $\bullet$ & High BOD accelerates bacteria activities and consumes oxygen. \\
\hline $\begin{array}{l}\text { Wastewater } \\
\text { temperature }\end{array}$ & - & $\begin{array}{l}\text { High temperature increases the microbial activity level in the slime layer. } \\
\text { High temperature reduces the oxygen solubility in wastewater. }\end{array}$ \\
\hline Flow velocity & - & $\begin{array}{l}\text { High velocity accelerates the aeration of wastewater, so it increases the oxidation of } \\
\mathrm{H}_{2} \mathrm{~S}, \text { resulting in the lowered potential for sulfide build up. }\end{array}$ \\
\hline Retention time & $\bullet$ & $\begin{array}{l}\text { Long retention time depletes the DO in wastewater. } \\
\text { Long retention time results in a loose slime layer that is easy for sulfate to penetrate. }\end{array}$ \\
\hline
\end{tabular}

\section{2. $\mathrm{H}_{2} \mathrm{~S}$ Release from Sewage and Subsequent Sulfide Buildup at Crown}

$\mathrm{H}_{2} \mathrm{~S}$ dissolves in sewage after it is diffused through the slime layer. The dissolved $\mathrm{H}_{2} \mathrm{~S}$ can exist as both aqueous $\mathrm{H}_{2} \mathrm{~S}$ and $\mathrm{HS}^{-}$in wastewater, depending on the $\mathrm{pH}$ value. The reaction equilibrium (Equation (2)) determines the amount of aqueous $\mathrm{H}_{2} \mathrm{~S}$ in sewage. On the one hand, at a pH of 6, near $100 \%$ sulfur exist as aqueous $\mathrm{H}_{2} \mathrm{~S}$ in wastewater. On the other hand, when the $\mathrm{pH}$ rises to $9, \mathrm{H}_{2} \mathrm{~S}$ content decreases significantly, and nearly $100 \%$ sulfur exists as $\mathrm{HS}^{-}$[15]. The typical $\mathrm{pH}$ of sewage is in the range of 6 to 8 [17]. Thus, a large amount of sulfide exists as aqueous $\mathrm{H}_{2} \mathrm{~S}$. The aqueous $\mathrm{H}_{2} \mathrm{~S}$ then is released in gaseous form from the sewage and disperses throughout the atmosphere in the sewer. This gaseous $\mathrm{H}_{2} \mathrm{~S}$ is a significant issue because it causes the acid corrosion of concrete during the subsequent process of MIC. In addition, gaseous $\mathrm{H}_{2} \mathrm{~S}$ results in odor problems when released out of the sewer system.

$$
\mathrm{H}_{2} \mathrm{~S}(\mathrm{aq}) \leftrightarrow \mathrm{HS}^{-}+\mathrm{H}^{+}
$$

In addition to wastewater $\mathrm{pH}$, the other two important factors that affect the release of aqueous $\mathrm{H}_{2} \mathrm{~S}$ are wastewater temperature and turbulence. They are summarized in Table 2. The first is the wastewater temperature-a high temperature improves the release of $\mathrm{H}_{2} \mathrm{~S}$ by reducing the solubility of $\mathrm{H}_{2} \mathrm{~S}$. For example, it is reported that a variation of $\mathrm{H}_{2} \mathrm{~S}$ concentration at the crown corresponds with a daily variation in temperature [10]. The other factor is the turbulence-a strong turbulence directly exacerbates the release process of $\mathrm{H}_{2} \mathrm{~S}$ from sewage to the crown of the pipe. For instance, severe acid corrosion is often spotted in turbulent areas such as drop manholes, lift stations, and junction boxes [18]. Rather than these designated locations, strong turbulence can also result from high flow velocities or poor sewer construction.

After the release of gaseous $\mathrm{H}_{2} \mathrm{~S}$ into the sewer atmosphere, there is a sulfide buildup at the tunnel crown. That is, gaseous $\mathrm{H}_{2} \mathrm{~S}$ accumulates and dissolves around the tunnel crown. This buildup plays an essential role in MIC of concrete. There is a general idea that a higher gaseous $\mathrm{H}_{2} \mathrm{~S}$ concentration in the crown causes a higher level of corrosion. However, the relationship between $\mathrm{H}_{2} \mathrm{~S}$ concentration and the MIC rate remains unclear $[19,20]$. A wide range of $\mathrm{H}_{2} \mathrm{~S}$ concentration-from $2 \mathrm{ppm}$ to several hundred ppm - can trigger severe acid corrosion [21]. For example, severe corrosion was also reported in a low concentration environment (e.g., 4 ppm) [13].

Table 2. Summary of factors affecting $\mathrm{H}_{2} \mathrm{~S}$ buildup.

\begin{tabular}{ll}
\hline Factors & Effects \\
\hline Wastewater $\mathrm{pH}$ & Wastewater $\mathrm{pH}$ affects the $\mathrm{H}_{2} \mathrm{~S}_{(\mathrm{aq})}$ concentration in sewage \\
Wastewater temperature & Low temperature reduces the $\mathrm{H}_{2} \mathrm{~S}$ solubility in sewage \\
Turbulence & Strong turbulence exacerbates the $\mathrm{H}_{2} \mathrm{~S}$ release by increasing the area of sewage-air interface \\
\hline
\end{tabular}




\subsection{Carbonation of Concrete Surface}

Along with sulfide buildup, carbonation co-occurs at the tunnel crown (see Figure 3). Carbonation is a reaction between carbon dioxide and one of the concrete compounds (e.g., calcium hydroxide). Carbonation occurs when concrete is exposed to air.

$$
\mathrm{Ca}(\mathrm{OH})_{2}+\mathrm{CO}_{2} \rightarrow \mathrm{CaCO}_{3}+\mathrm{H}_{2} \mathrm{O}
$$

Carbonation is a very slow process. The rate of carbonation is highly dependent on relative humidity (RH). The highest rates of carbonation occur when $\mathrm{RH}$ is in the range of $50 \%$ to $75 \%$; $\mathrm{CO} 2$ penetration would be restricted above $75 \% \mathrm{RH}$ [22], thereby inhibiting the carbonation rate. Another factor that affects the carbonation rate is the permeability of the concrete. Low permeability concrete experiences slower carbonation than relatively permeable concrete because of the inhibited $\mathrm{CO}_{2}$ penetration [23]. The low permeability usually comes with a low water-to-cement ratio and proper curing, leading to less carbonation [22]. Table 3 summarizes the effects of $\mathrm{RH}$ and permeability on the carbonation rate.

Table 3. Summary of factors affecting carbonation rate.

\begin{tabular}{ll}
\hline Factors & Effects \\
\hline $\mathrm{RH}$ & $\begin{array}{l}\text { The highest rates of carbonation occur in environments in which the } \mathrm{RH} \text { of the } \\
\text { surrounding atmosphere is kept in the range of } 50 \% \text { to } 75 \%[22] .\end{array}$ \\
\hline Permeability & $\begin{array}{l}\text { Low permeability inhibits the penetration of } \mathrm{CO}_{2}, \text { restricting the carbonation to the } \\
\text { concrete surface. }\end{array}$ \\
\hline
\end{tabular}

Carbonation reduces the concrete surface $\mathrm{pH}$ by consuming alkaline calcium hydroxide (Equation (3)); as a result, the concrete surface $\mathrm{pH}$ decreases from $12-13$ to as low as 8.5 [23]. This low $\mathrm{pH}$ is suitable to colonize microorganisms at the crown surface of the tunnel, allowing a further microbial process-sulfide oxidation.

\subsection{Sulfide Oxidation}

In this process, the $\mathrm{H}_{2} \mathrm{~S}$ is oxidized into sulfuric acid $\left(\mathrm{H}_{2} \mathrm{SO}_{4}\right)$ through bacteria activities. First, moisture in the tunnel atmosphere condenses on the concrete wall, forming a moisture film. Then, due to carbonation, the surface $\mathrm{pH}$ of the concrete drops to around $\sim 9$, and the SOB starts to colonize on the crown of the tunnel [21]. The $\mathrm{H}_{2} \mathrm{~S}$ dissolved in the moisture film during the sulfide buildup is then oxidized by the SOB, which forms sulfuric acid.

The sulfuric acid formation is mainly affected by two factors: atmospheric temperature and RH (see Table 4). Atmospheric temperature is critical for the intensity of microbial activities. High atmospheric temperature increase microbial activities [24,25], thereby raising the MIC rate. For example, the rates of sulfide oxidation at $25{ }^{\circ} \mathrm{C}$ were found $15 \%$ higher than those at $20^{\circ} \mathrm{C}$ [21]. Temperature below $15.6^{\circ} \mathrm{C}$ inhibits the bacteria's sulfide-oxidizing activity [26]. $\mathrm{RH}$ is the other influencing factor of the sulfuric acid formation. A minimum value of $87 \% \mathrm{RH}$ is required for bacteria to be active [27]. In general, high humidity increases the rate at which sulfuric acid forms [28]. For example, the $\mathrm{pH}$ in a concrete surface was reduced more significantly when the $\mathrm{RH}$ was $95-100 \%$ than when the RH was 85-95\% [29]. In other words, more sulfuric acid forms when the RH is between $95 \%$ and $100 \%$.

Table 4. Summary of factors affecting $\mathrm{H}_{2} \mathrm{SO}_{4}$ generation.

\begin{tabular}{ll}
\hline Factors & Effects \\
\hline $\mathrm{RH}$ & High $\mathrm{RH}$ increases the rate of $\mathrm{H}_{2} \mathrm{SO}_{4}$ generation \\
Atmosphere temperature & High temperature accelerates microbial activities at the crown \\
\hline
\end{tabular}




\subsection{Acid Corrosion Reaction}

Because of its alkaline nature, concrete decomposes easily after sulfuric acid forms. In this process, aggressive ions in the sulfuric acid (i.e., $\mathrm{H}^{+}$and $\mathrm{SO}_{4}{ }^{2-}$ ) first penetrate the pore structures of the concrete, and then these ions react with hydration products such as calcium hydroxide $\left(\mathrm{Ca}(\mathrm{OH})_{2}\right)$ and calcium silica hydrate $\left(\mathrm{CaO} \cdot \mathrm{SiO}_{2} \cdot 2 \mathrm{H}_{2} \mathrm{O}\right)$ (see Equation (4)). One immediate product is gypsum $\left(\mathrm{CaSO}_{4}\right)$, which is expansive- the volume increases by $124 \%[30,31]$.

$$
\begin{gathered}
\mathrm{H}_{2} \mathrm{SO}_{4}+\mathrm{CaOSiO}_{2} \cdot 2 \mathrm{H}_{2} \mathrm{O} \rightarrow \mathrm{CaSO}_{4}+\mathrm{Si}(\mathrm{OH})_{2}+2 \mathrm{H}_{2} \mathrm{O} \\
\mathrm{H}_{2} \mathrm{SO}_{4}+\mathrm{Ca}(\mathrm{OH})_{2} \rightarrow \mathrm{CaSO}_{4}+2 \mathrm{H}_{2} \mathrm{O}
\end{gathered}
$$

Then, a subsequent reaction (see Equation (5)) occurs between gypsum and tricalcium aluminates. This reaction is destructive due to the formation of ettringite $\left(3 \mathrm{CaO} \cdot \mathrm{Al}_{2} \mathrm{O}_{3} \cdot 3 \mathrm{CaSO}_{4} \cdot 31 \mathrm{H}_{2} \mathrm{O}\right)$ which expands the volume by $\sim 227-700 \%$ [30-32]. The continuing generation of ettringite causes internal peeling and cracking, and finally leads to hydration products being removed from the congregate, and the concrete losing its integrity.

$$
\mathrm{CaSO}_{4}+3 \mathrm{CaO} \cdot \mathrm{Al}_{2} \mathrm{O}_{3} \cdot 6 \mathrm{H}_{2} \mathrm{O}+25 \mathrm{H}_{2} \mathrm{O} \rightarrow 3 \mathrm{CaO} \cdot \mathrm{Al}_{2} \mathrm{O}_{3} \cdot 3 \mathrm{CaSO}_{4} \cdot 31 \mathrm{H}_{2} \mathrm{O}
$$

The chemical corrosion reaction rate is greatly regulated by the mixture design of concrete. For example, the acid corrosion rate decreased when calcareous aggregates were used in the mixture. This increases the alkalinity of the concrete surface and creates a local buffering environment for cement binder [33]. This research also observed higher levels of deterioration in concrete samples with higher cement content and lower water/cement ratios. In addition to concrete alkalinity, the porosity/permeability is considered the most important intrinsic property for predicting the durability of hardened concrete [10]. This also applies to the acid corrosion because aggressive sulfuric acid needs to penetrate through pore structures before attacking the inner part of the concrete. Therefore, when the mixture is designed properly, concrete can reach a low porosity that limits the corrosion rate. Another factor that changes the corrosion reaction rate is atmospheric temperature. Higher temperatures raise corrosion reaction rates [24]. Table 5 summarizes the factors affecting the corrosion reaction rate.

Table 5. Summary of factors affecting the corrosion reaction rate.

\begin{tabular}{ll}
\hline Factors & Effects \\
\hline Porosity & High porosity enhances the penetration of aggressive ions \\
Atmosphere temperature & High temperature accelerates the corrosion reaction rate \\
\hline
\end{tabular}

\section{Discussions about Potential Methods to Control Microbially Induced Corrosion}

This section focuses on the potential methods to control MIC in the light of corrosion mechanism. As previously discussed, the rate of the MIC process is affected by many factors (summarized in Table 6). When these factors are controlled, the acid corrosion on drainage concrete may be mitigated or even prevented. Generally, these factors can be classified into three categories: environmental factors, sewer hydraulic parameters, and concrete mixture design. Environmental factors include $\mathrm{RH}$, $\mathrm{DO}, \mathrm{BOD}$, wastewater temperature, atmospheric temperature, and wastewater $\mathrm{pH}$; sewer hydraulic design parameters include flow velocity, turbulence, and retention; and concrete design parameters include porosity/permeability and alkalinity. In general, sewer hydraulic parameters mainly affect the processes of $\mathrm{H}_{2} \mathrm{~S}$ generation and the buildup process while proper concrete design reduces the corrosion reaction rate. Environmental factors can alter the rate of several subprocesses within the MIC. The control methods falling into these three categories are investigated and summarized in the following section. 
Table 6. Summary of factors affecting MIC rate.

\begin{tabular}{|c|c|}
\hline Factors & Effects \\
\hline RH & $\begin{array}{l}\text { - The highest rates of carbonation occur in environments in which the } \mathrm{RH} \text { of the } \\
\text { surrounding atmosphere is between } 50 \% \text { and } 75 \% \text { [22]. } \\
\text { - A high } \mathrm{RH} \text { increases the rate of } \mathrm{H}_{2} \mathrm{SO}_{4} \text { generation }\end{array}$ \\
\hline Porosity/Permeability & $\begin{array}{l}\text { - Low permeability inhibits the penetration of } \mathrm{CO}_{2} \text {, restricting the carbonation to the } \\
\text { concrete surface. } \\
\text { - High porosity enhances the penetration of aggressive ions }\end{array}$ \\
\hline DO & $\begin{array}{l}\text { - A high DO increases the oxidation of } \mathrm{H}_{2} \mathrm{~S} \text {, thereby reducing the release of } \mathrm{H}_{2} \mathrm{~S} \text { from } \\
\text { the slime layer }\end{array}$ \\
\hline BOD & - A high BOD encourages bacteria activities that consume DO \\
\hline Wastewater temperature & $\begin{array}{l}\text { - A high temperature increases the microbial activity level in the slime layer } \\
\text { - }\end{array}$ \\
\hline Atmosphere temperature & $\begin{array}{l}\text { - A high temperature accelerates the corrosion reaction rate } \\
\text { - A high temperature increases the microbial activity level at the crown }\end{array}$ \\
\hline Flow Velocity & $\begin{array}{l}\text { - A high flow velocity encourages re-aeration resulting in the growth of } \\
\text { sulfur-oxidizing bacteria (SOB), hence encourages chemical oxidation resulting in } \\
\text { lowered potential for sulfide buildup }\end{array}$ \\
\hline Turbulence & $\begin{array}{l}\text { - A strong turbulence exacerbates } \mathrm{H}_{2} \mathrm{~S} \text { release by increasing the area of } \\
\text { sewage-air interface }\end{array}$ \\
\hline Retention time & $\begin{array}{l}\text { - A long retention time depletes the DO in wastewater } \\
\text { - A long retention time results in a loose slime layer, which is easy for sulfate } \\
\text { penetration, hence increasing SRB activities. }\end{array}$ \\
\hline Wastewater $\mathrm{pH}$ & $\begin{array}{l}\text { - Typical sewage } \mathrm{pH} \text { ranges between } 6 \text { and } 8 \text { [17]. It affects the } \mathrm{H}_{2} \mathrm{~S}_{(\mathrm{aq})} \text { concentration } \\
\text { in sewage. }\end{array}$ \\
\hline
\end{tabular}

\subsection{Changing Sewer Tunnel Environment}

The first category of control methods is achieved by changing the sewer environment. The sewer tunnel environment includes the wastewater (sewage) and the tunnel atmosphere. The available control methods that the authors are aware of tend to adjust wastewater conditions by adding chemicals to the wastewater. Many chemicals dosed to the sewage have been effective in reducing sulfide concentrations in sewage. These chemicals include magnesium hydroxide, sodium hydroxide, iron salts, free nitrous acid (FNA), nitrate, oxygen, hydrogen peroxide, ozone, chlorine, and permanganate. There are three main mechanisms for these chemicals in controlling MIC: (1) raising the $\mathrm{pH}$ of sewage and hence reducing the $\mathrm{H}_{2} \mathrm{~S}$ state sulfide in sewage, such as by using magnesium hydroxide and sodium hydroxide [34]; (2) inhibiting SRB growth, thus reducing the production of sulfide, such as by using iron salt [35,36], FNA [37], nitrate [38-40], magnesium hydroxide and sodium hydroxide; and (3) oxidizing sulfide directly, such as by using oxygen [41], ozone, hydrogen peroxide, chloride and permanganate [42].

There are many drawbacks to these chemical-adding methods, beginning with the high cost of the required continuous dosing to the sewage. In addition, some chemicals dosed into the sewage can cause environmental problems. For example, unwanted chemicals may be generated as a result of the dosed chemical and the chemicals already in the sewage [21].

\subsection{Using Proper Hydraulic Parameters in Sewer Design}

The second category of control methods is the use of appropriate hydraulic parameters in design. These parameters include sewage flow velocity, retention, and turbulence [15]. In general, high velocity in the flow stream increases the $\mathrm{DO}$ level and accordingly reduces the aqueous $\mathrm{H}_{2} \mathrm{~S}$ content 
in sewage [16], while sudden turbulence enhances the release of $\mathrm{H}_{2} \mathrm{~S}$ which accelerates the MIC process [10]. The DO level of sewage is key to the $\mathrm{H}_{2} \mathrm{~S}$ generation process. A high flow velocity of sewage enhances the turbulent diffusion of atmospheric oxygen into water, so it increases the DO level in wastewater. This high DO intensifies the oxidation of $\mathrm{H}_{2} \mathrm{~S}$ during its diffusion back to sewage; hence, it reduces the aqueous $\mathrm{H}_{2} \mathrm{~S}$ content in wastewater. Above a certain flow velocity, there will be no generation of $\mathrm{H}_{2} \mathrm{~S}[43,44]$. In other words, low velocity and long retention time should be avoided in sewer system design to prevent DO depletion under such conditions. In practice, wastewater storage in pump stations and debris and sediment buildup in sewers are common sources for the long retention of wastewater in sewer systems. These locations tend to trap sulfate and organic matters, leading to more active SRB. This causes the high content of aqueous $\mathrm{H}_{2} \mathrm{~S}$ in wastewater. In this case, when $\mathrm{H}_{2} \mathrm{~S}$ has already appeared in sewage, high velocity/turbulence accelerates the release of $\mathrm{H}_{2} \mathrm{~S}$ from wastewater to the tunnel crown. There are many potential sources of turbulence in sewer systems: a hydraulic drop in a manhole, discharge from force mains, sharp bends, junctions, and sections with steep slopes [16].

Accordingly, some locations are particularly susceptible to MIC. These include locations with high turbulence where upstream have long retention or low velocity [15]. One example of such a location is a force main from which water is discharged. Wastewater, stored in the wet well of a pump station, is pumped through the force main and released to the sewer tunnels at the discharge. Long retention in wet well provides the perfect condition for the $\mathrm{H}_{2} \mathrm{~S}$ generation, while the high turbulence at the discharge of force main enhances the release of $\mathrm{H}_{2} \mathrm{~S}$. Note that full flow in the force main will also increase the $\mathrm{H}_{2} \mathrm{~S}$ generation since no atmospheric oxygen is available to oxygenate the wastewater $[45,46]$. This further increases the potential for corrosion at the discharge.

In the authors' opinion, high velocity in the flow stream is recommended in sewer design, while sudden turbulence such as hydraulic jump should be reduced. When long retention and undue turbulence are impossible to avoid, proper supplementary measures should be taken to control concrete corrosion:

1. When debris and sediment buildup cause long retention or low flow velocity, a good maintenance plan is more efficient than proper tunnel design to minimize the buildup of hydrogen sulfide.

2. When the long retention is caused by the storage of wastewater-at locations such as pump stations-chemical dosing to the wastewater in a wet well will greatly reduce the chance of $\mathrm{H}_{2} \mathrm{~S}$ generation [47].

3. When sudden turbulence is inevitable, the quality of wastewater upstream of the turbulence should be carefully evaluated before selecting the pipe material.

\subsection{Improving Concrete Mixture Design}

The third category of control methods has to do with improving the concrete mixture design. Note that acid corrosion is unavoidable because the cement-based concrete is alkaline in nature, and decomposes under an acid environment [22]. However, improving the concrete mixture design is still a viable method because it changes the rate of the corrosion reaction process. Here, two additives are taken as examples in the concrete mixture design: one is the addition of pozzolans, and the other is the introduction of biocides.

The first type of additives are pozzolans. Some researchers partially replaced cement with pozzolans (e.g., ground granulated blast furnace slag, rice husk ash, pulverized fuel ash, palm oil fuel ash, silica fume, fly ash and metakaolin) [48]. The incorporation of pozzolans generally changes the acid resistance of concrete in two aspects: the change of chemical compositions and the reduction of porosity. The first aspect is the change of the chemical compositions due to pozzolanic reaction. When added in the mixture, pozzolans chemically reacts with calcium hydrate $\mathrm{Ca}(\mathrm{OH})_{2}$ in the concrete matrix forming extra calcium-silicate-hydrate (CSH) which possess cementitious properties [49]. This reaction is called the pozzolanic reaction, which consumes the $\mathrm{Ca}(\mathrm{OH})_{2}$ that is believed to be the primary reason for the poor acid resistance of plain concrete [50]. The reduced content of $\mathrm{Ca}(\mathrm{OH})_{2}$ in concrete through pozzolanic reaction results in the lesser formation of expansive corrosion 
products in acid attack [51]. This mitigates the corrosion rate of concrete under acidic environment. Furthermore, the extra calcium-silicate-hydrate (CSH) from pozzolanic reaction, is more stable than $\mathrm{Ca}(\mathrm{OH})_{2}$ under an acidic environment [52]. In addition to the chemical compositions, the second aspect is the reduction of porosity. The addition of pozzolans refines the pore structures of concrete and reduces its porosity. This is due to the CSH produced from pozzolanic reactions and the filling of small pozzolans particles $[53,54]$. The porosity is crucial to the acid resistance of concrete because it affects the penetration of aggressive ions from acids into concrete [55]. A higher porosity causes a larger diffusion of the aggressive ions into concrete, which increases the contact area between cement hydrates and the aggressive ions [56]. In other words, a lower corrosion could be expected in concrete with a lower porosity - this has been supported by many studies. For example, Chatveera et al. [57] found that a more porous concrete tends to show more negative effect from the acid attack. In addition, some other literature [49] reported the improvement in resistance to harmful solutions due to the refined concrete pore structure. However, the reduced porosity does not guarantee a better acid resistance of concrete. Under severe sulfuric acid attack, Senhadji et al. [58] found that refining the porosity had little effect on the improvement of the acid resistance. They observed that the addition of silica fume reduced the porosity of concrete, but the acid deterioration of concrete was not effectively prevented. Besides that, some controversial results were also reported regarding the effectiveness of pozzolan addition. Some studies observed opposite results [59-61] of pozzolan addition on acid resistance owing to variations in experimental conditions and the chemical composition of differently sourced pozzolans. Therefore, the chemical compositions of pozzolans should be individually examined, and experimental conditions should be mimicked as close as possible to the real sewer conditions before using it in an actual sewer. In this way, a better determination can be made whether they are effective at improving corrosion resistance.

Apart from the pozzolanic materials, the innovative addition of biocides into concrete mixture provides another possibility in combating MIC in sewer tunnels. For example, the addition of Conshield to concrete mixes inhibits the SOB (e.g., Thiobacillus) colonies on the concrete surface [62]. Different from pozzolans, Conshield is a highly charged cationic polymer that kills the gram-negative Thiobacillus on a concrete surface. As previously mentioned, the Thiobacillus on the tunnel crown converts the $\mathrm{H}_{2} \mathrm{~S}$ into sulfuric acid. The elimination of bacteria could prevent the generation of aggressive acid, which cuts off the MIC process fundamentally. However, this material has not been widely used due to the concerns from industry that the cationic polymer is consumptive, and the SOB may finally colonize the concrete surface when it is depleted. Besides Conshield, some literature has investigated many other materials for their use as biocidal additives in concrete. For instance, Park et al. [63] examined the effectiveness of Zeolite and Zeocarbon microcapsules on the prevention of fungi growth in concrete. In their study, no fungus growth was observed on the surface of concrete. Freed [64] patented reinforced concrete containing antimicrobial-enhanced fibers, which aimed to reduce the susceptibility of concrete against biogenetic attack. Although the addition of these materials has been verified to be effective for some microorganisms, their biocidal effects towards the SOB have not been examined. More research is needed specifically for combatting MIC in sewer tunnels.

\subsection{Other Methods}

In addition to previous three categories of control methods, there are more options to control MIC, and the number is still increasing. One of these methods is surface treatment on concrete. As the name suggests, surface treatment is a technology that uses physical or chemical additives sprayed on the surface of a concrete liner, so the SOB can be inhibited or deactivated. For example, coating with a sacrificial layer, such as magnesium, increases the surface $\mathrm{pH}$, which inhibits bacterial colonization [65]; coating with incorrodible materials, such as epoxy [66], prevents concrete from coming into contact with the corrosive environment. Additionally, recent research reported that high-pressure washing increases the concrete surface $\mathrm{pH}$ by removing the corrosion layer and consequently decreasing the 
bacteria. However, it only took 60-140 days for the SOB to recover to its pre-washing level [67]. The disadvantages of these methods are summarized in Table 7.

Table 7. Disadvantages of coating and surface wash.

\begin{tabular}{|c|c|}
\hline Methods & Disadvantages \\
\hline Coating with sacrificial layer & $\begin{array}{l}\text { - Applying the sacrificial layer requires regular treatment and } \\
\text { preparation of concrete surface. } \\
\text { - The sacrificial material is costly. }\end{array}$ \\
\hline Coating with incorrodible materials & - Some coating chemicals are not environmentally friendly. \\
\hline Surface wash & $\begin{array}{l}\text { - It is effective only in the short term. } \\
\text { - } \quad \text { Must frequently be repeated. }\end{array}$ \\
\hline
\end{tabular}

\section{Rehabilitation}

In addition to the control methods, another important aspect in combatting MIC is the approach to make deteriorated structure functional again - this is called rehabilitation. In rehabilitating sewers deteriorated by MIC, there are three categories of techniques: repair, renewal, and replacement. The progression from repair to renewal to replacement requires increasing investment, targeting at decreasing level of concrete integrity [68]. As summarized in Figure 5, many rehabilitation methods are currently available, including point repair, shotcrete, cured-in-place pipe (CIPP), slip lining, fold-and-form pipe, and epoxy coating. Each method may be capable of one or more categories of rehabilitation. Renewal or replacement is often required to rehabilitate sewer infrastructure severely corroded by the MIC, and there are many technologies available for this, as shown in Figure 5. However, this paper will only investigate the advantages and limitations of cement-based renewal technologies and materials. Note that the term "renewal" is interchangeable with "rehabilitation" in the sewer industry. This paper follows the same convention.

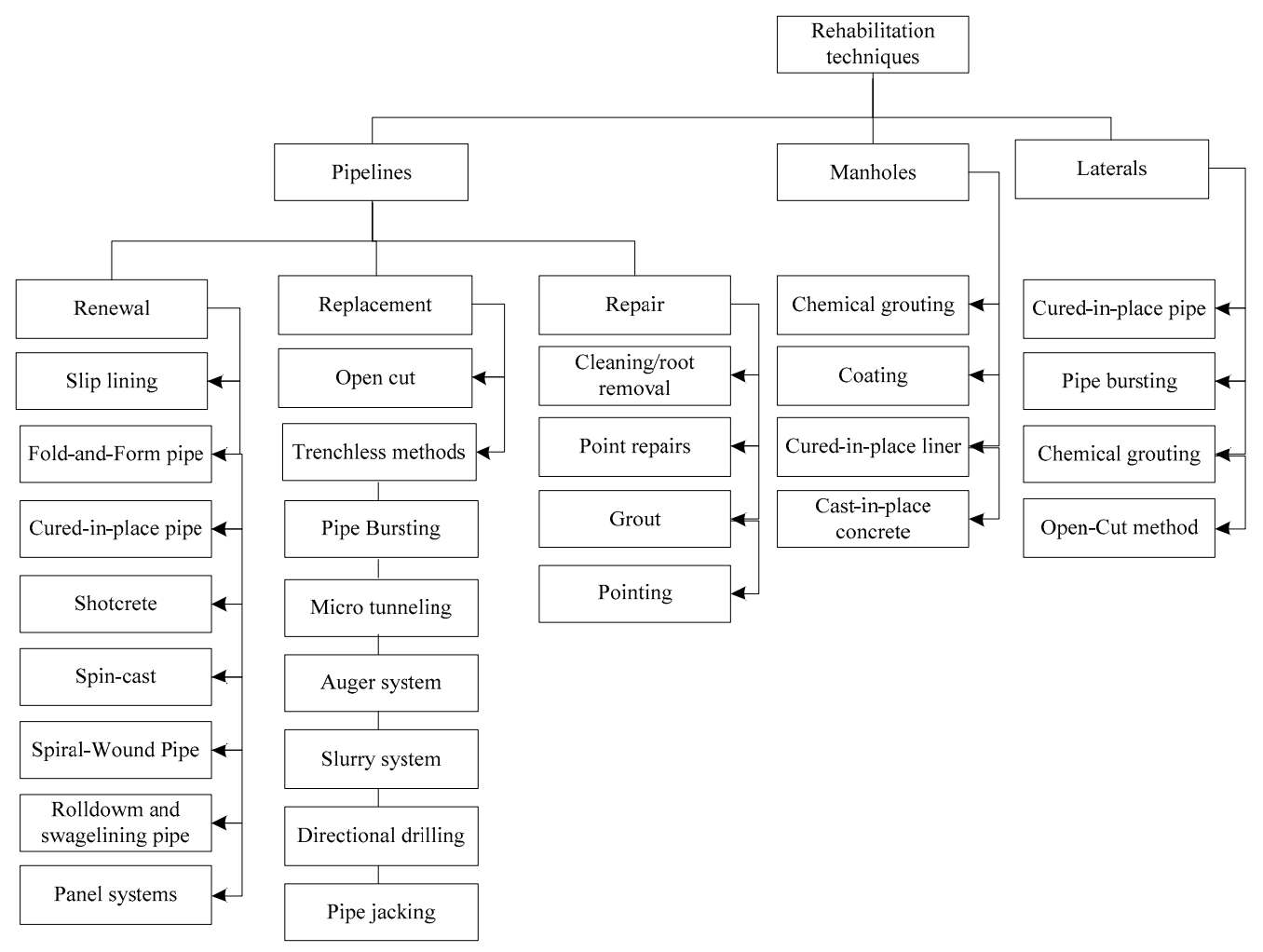

Figure 5. Rehabilitation techniques. 


\subsection{Cement-Based Rehabilitation Techniques}

Cement-based rehabilitation methods are actively used in severely deteriorated sanitary sewer tunnels because of their excellent mechanical and bonding performance on damp surfaces. They can provide structural rehabilitation to deteriorated sanitary tunnels, where the existing pipe acts merely as a right-of-way in the liner installation [69]. Cement-based materials can be sprayed (shotcrete), pumped (cast-in-place concrete), and spin cast. More details are explained in the following section.

\subsubsection{Shotcrete}

Shotcrete is the method of pneumatically spraying fresh cement-based mixtures onto a surface through a hose at a high velocity [70]. There are two types of processes-wet-mix and dry-mix. In the dry-mix process, water is added at the nozzle, while, in the wet-mix process, all ingredients are mixed with water before being introduced to the delivery hose and the nozzle. As shown in Figure 6, shotcrete mixture is conveyed through a hosepipe and then sprayed via a nozzle onto the corroded tunnel wall. During the rehabilitation, mesh is often incorporated in operation to limit cracking and provide structural support.

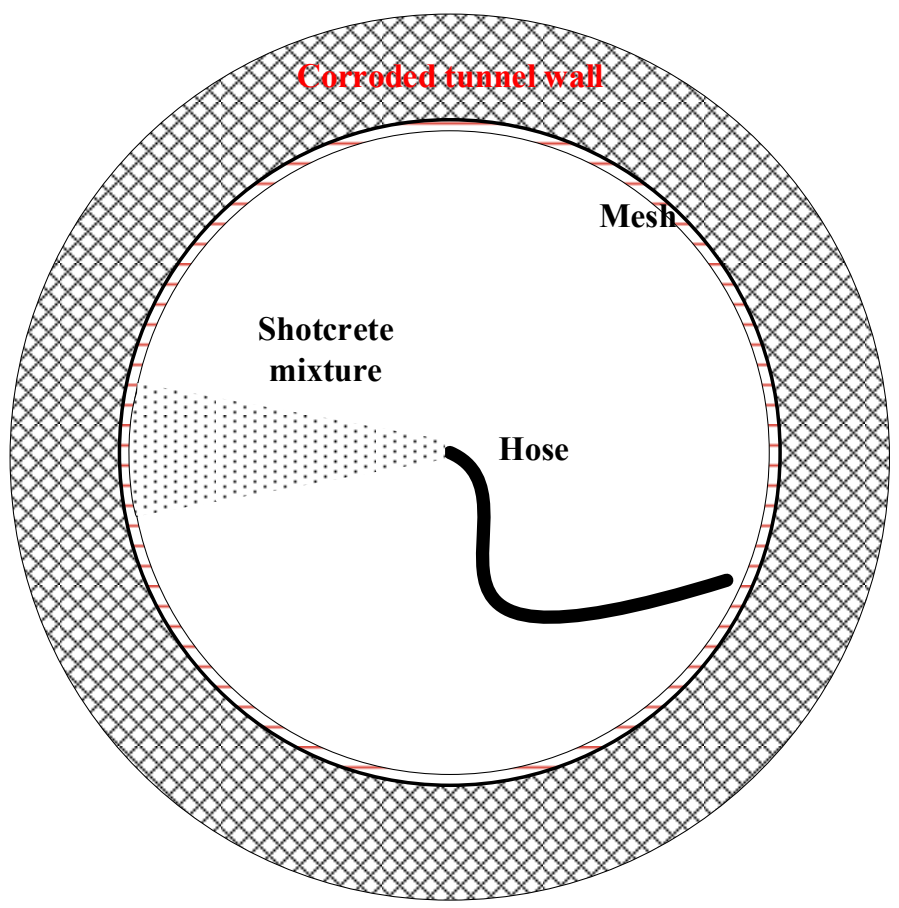

Figure 6. A schematic showing the shotcrete rehabilitation process.

Shotcrete has been actively used as a flexible and economic rehabilitation technique for sewer tunnels, providing better performance than conventional concrete. Shotcrete's high-speed pneumatic projection provides enhanced compaction, resulting in superior bonding characteristics and strength. It also gains increased density and reduced permeability. The high density and low permeability reduce the penetration of the aggressive solution into the concrete pore structures [71]. Consequently, shotcrete demonstrates more improved acid resistance than ordinary cast concrete [68]. In addition, shotcrete eliminates the necessity of formwork or an assembly system; thus, it can be applied at a faster rate and lower cost than conventional concrete placement methods.

However, there are limitations to using shotcrete in sewer tunnel rehabilitation. The first limitation is rebound, in which large aggregates with cement and sand bounce off the receiving wall. The second limitation is that shotcrete has a relatively rough surface, which increases the Manning's value and causes an accumulation of sediment and organic matter. This could, directly and indirectly, accelerate 
the MIC progress. Thus, after shotcrete is applied in a sewer tunnel, troweling is highly recommended to make the surface smooth. In addition, in-situ shotcrete is not applicable in small diameter sewers, manholes and other structures because it requires personnel entry, and equipment and material handling. The preferred diameter for shotcreting is approximately $122 \mathrm{~cm}$ and larger [68].

\subsubsection{Cast-in-Place Method}

Cast-in-place concrete is an effective rehabilitation method for a variety of sewer shapes. The designed steel mesh is affixed to the existing pipe as reinforcement. As shown in Figure 7, formwork (slip-forms or fixed-forms) are set up to provide the finished wall section prior to concrete placement [68]. The gap between the formwork and the tunnel wall is the annular space that will be filled later. A venting or overflow hole is required at the highest point of the formwork that not only provides a path for air to escape when fresh concrete is injected. This venting hole also informs the worker to stop grouting when it is overflowed [72,73]. After the formwork, a grouting pipe can be laid in the crown of the sewer tunnel. Then concrete ingredients are introduced and mixed in the grout plant on the ground. The readily mixed fresh mixture is next pumped to the grouting location through the pipe laid on the crown of formwork. When the venting hole is overflowed, the grout operation stops, and then the venting hole is sealed with a plug.

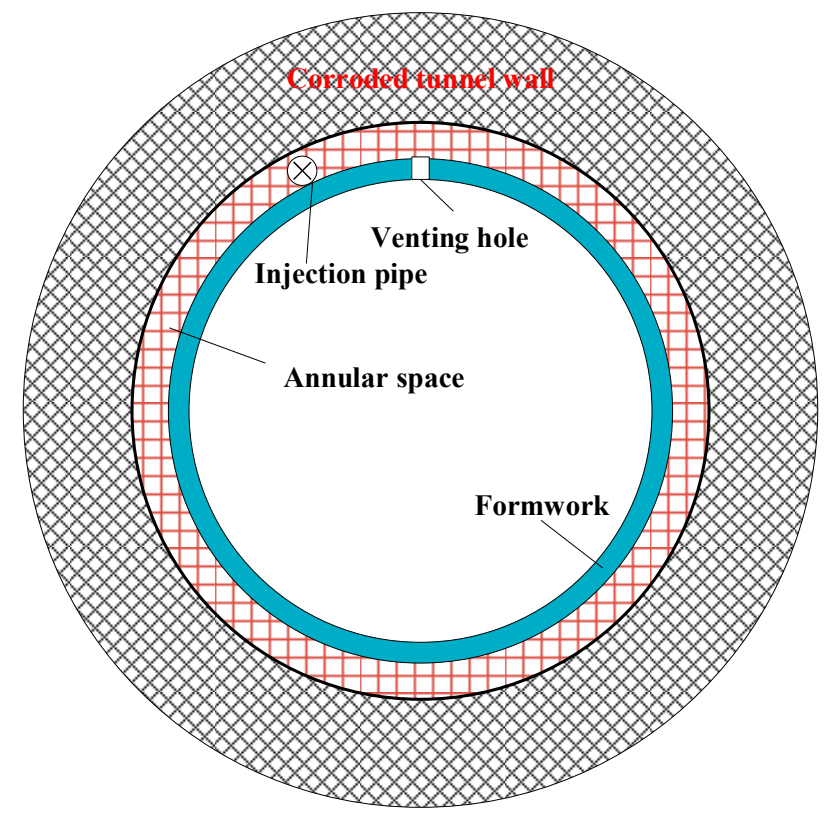

Figure 7. A schematic showing the cast-in-place rehabilitation process.

Studies reviewed for this paper showed that the cast-in-place method is seldom used in sewer rehabilitation. A recent literature review revealed only two documents [68,72] indicating such a use of the cast-in-place method. Possible reasons that this method is not widely used are that it requires extensive formwork and a minimum sewer diameter (approximately $122 \mathrm{~cm}$ or larger), and the material handling is labor-intensive.

\subsubsection{Spin-Cast Method}

The spin cast is an automated process that uses centrifugal force to spin cementitious materials onto the tunnel wall; it is an effective rehabilitation method for circular or near-circular sewers. First, a pumping plant is set up on the ground. Similar to cast-in-place method, all ingredients are introduced and mixed here. However, no coarse aggregates are introduced in spin-cast method. Then the readily mixed paste is transported to a spincaster (see Figure 8) that is located in the tunnel. During 
rehabilitation, the spincaster rotates and sprays cementitious materials onto the old, corroded structure. This centrifugal projection produces a densely packed lining with little rebound [74]. As the projection proceeds, the spincaster moves along the tunnel axis. Theoretically, a thickness of one inch $(25 \mathrm{~mm})$ or more can be reached per pass [75]. Unlike the cast-in-place method, there is no need for man-entry in the confined sewer space; this makes spin-cast a safer technique that can be used in smaller sewer pipes. The major limitation is the difficulty in ensuring that the rehabilitation materials are distributed properly. In circular tunnels, spin-casting can provide uniform thickness if the spinning head is guided at a constant rate. However, for non-circular shapes, particularly shapes with sharp edges, it becomes almost impossible to achieve a uniform thickness of rehabilitation materials on the tunnel surface.

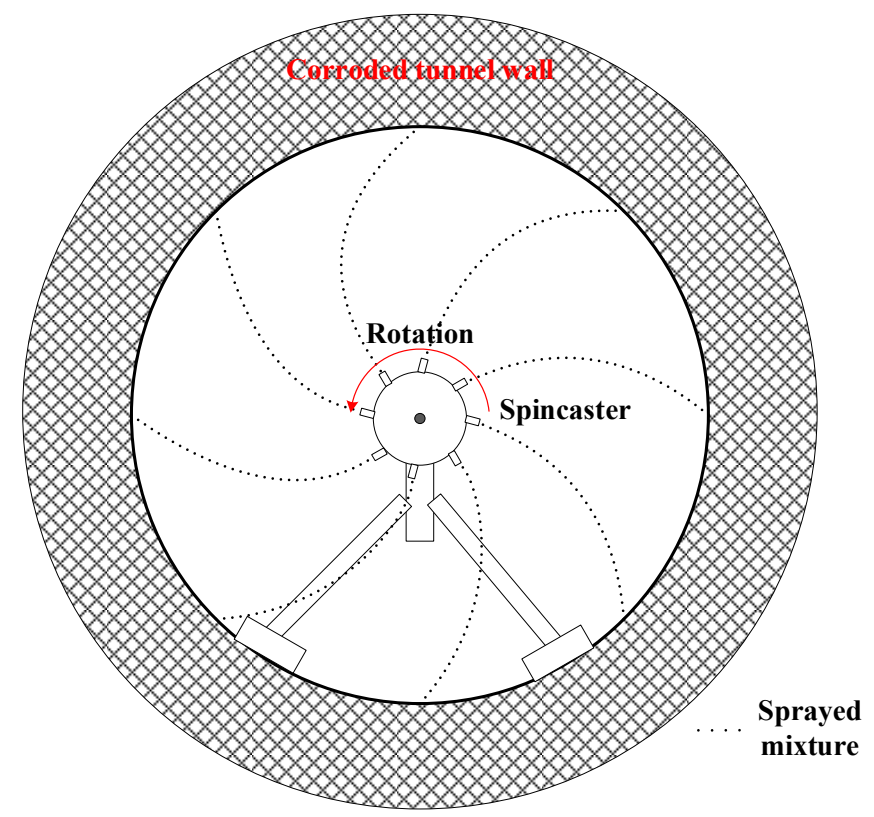

Figure 8. A schematic showing the Spin-cast rehabilitation process.

\subsection{Cement-Based Rehabilitation-Method Selection}

Rehabilitation methods and materials should be selected using criteria such as cost, inflow and infiltration (I \& I), pipe cleaning, corrosion resistance, by-pass possibility, level of deterioration (structural or non-structural), access, above-ground conditions (i.e., access and traffic limitations), and underground conditions (i.e., depth of the pipe, groundwater, and crossing utilities). Table 8 compares the three cement-based rehabilitation methods using some of these criteria. As mature techniques, the three aforementioned cement-based methods have several advantages. First, they can rehabilitate sewers with various levels of deteriorations because the thickness of the rehabilitation layer is adjustable. Second, fiber or wire mesh can be incorporated into cement-based mixtures to enhance the mechanical performance and structural support. Third, cementitious material bonds well to damp surfaces, providing excellent integrity to the rehabilitated structure. Finally, the mixture design is adjustable, so its chemical resistance can be improved through optimized mixture design.

However, cement-based methods also have their disadvantages. First, tunnel surfaces have to undergo intense preparation, and infiltration and inflow must be removed to ensure proper bonding with old pipe. Second, a flow by-pass plan is needed, which greatly increases the cost. Third, because cement-based rehabilitation techniques reduce the cross-sectional area in all repaired tunnels, the sewage transport capacity of sewer tunnel will be reduced after rehabilitation. Finally, cement-based materials are subject to acid corrosion: all hydraulic-cement concretes, regardless of the composition, are unable to withstand for long in an acid with a pH below 3 [22]. Precautions must be taken to ensure the acid resistance of these cement-based materials. 
Table 8. Summary of advantages and limitations of cement-based rehabilitation techniques.

\begin{tabular}{|c|c|c|}
\hline & Advantages & Limitations \\
\hline Spin-cast & $\begin{array}{l}\text { Cost-effective } \\
\text { Can be done without confined space entry } \\
\text { Can be used in small diameter pipes }\end{array}$ & $\begin{array}{l}\text { Limited acid resistance } \\
\text { Flow by-pass required } \\
\text { High level of cleaning required } \\
\text { Removal of I \& I required } \\
\text { Decreased cross-sectional area }\end{array}$ \\
\hline Shotcrete & $\begin{array}{l}\text { Fiber-reinforced shotcrete shows excellent } \\
\text { mechanical properties } \\
\text { Improved compaction resulting in } \\
\text { enhanced chemical resistance } \\
\text { Applicable in most sewer shapes }\end{array}$ & $\begin{array}{l}\text { Limited acid resistance } \\
\text { Flow by-pass required } \\
\text { High level of cleaning required } \\
\text { Removal of I \& I required } \\
\text { Decreased cross-sectional area } \\
\text { Applicable for tunnels with } \geq 35^{\prime \prime} \text { in diameter } \\
\text { Pumping length }<500 \mathrm{~m} \\
\text { Rebound impact }\end{array}$ \\
\hline $\begin{array}{l}\text { Cast-in-place } \\
\text { concrete }\end{array}$ & Effective for a variety of sewer shapes & $\begin{array}{l}\text { Limited acid resistance } \\
\text { Flow by-pass required } \\
\text { High level of cleaning required } \\
\text { Removal of I \& I required } \\
\text { Decreased cross-sectional area } \\
\text { Applicable for tunnels with } \geq 48^{\prime \prime} \text { in diameter } \\
\text { Formwork or assembly system required }\end{array}$ \\
\hline
\end{tabular}

\subsection{Cement-Based Rehabilitation-Material Selection Based on the Acid Resistance}

Acid resistance is the most important criterion to consider when selecting what kind of concrete/cementitious material to use in cement-based rehabilitation. Acid resistance is the term used to describe a material's ability to combat deterioration caused by acid [9]. However, it is not easy to evaluate acid resistance due to: (1) the lack of standard testing procedure; and (2) controversial results of acid resistance from various indicators. The first reason is the lack of standard specifying the testing procedure. This may lead to totally different results in different experiments for the same mix. The commonly used test procedure of assessment is to immerse concrete samples in an acid solution (known as the immersion method), which directly investigates the resistance of concrete to acid. Many researchers [48,51,76-82] have used this method to evaluate the effectiveness of supplementary cementitious materials (SCMs) in improving the acid resistance of the concrete. However, there are many drawbacks regarding the immersion method. First, this method requires long immersion time, often several months to several years. To shorten the test duration, acceleration is commonly required, such as increasing the testing temperature, using a high concentration of acid, a surface brush, and dry and wet cycling. Second, there is currently no standard specifying the detailed testing procedure, which may lead to totally different results in different experiments for the same mix. Variations in testing procedures and environmental conditions (e.g., temperature, concrete surface area-to-acid volume ratio, the frequency of acid replenishment, acid strength) can significantly alter the results. For example, improved acid resistance was found for silica fume concrete immersed in $1 \%$ sulfuric acid. However, Hewayde and Nehdi et al. [61] found little difference between the reference sample and silica fume samples with up to 15\% replacement ratio after 61 days of immersion in 3\% and 7\% sulfuric acid. They concluded that this was attributed to the excessive acid concentration. Third, for the microbially induced corrosion (MIC) process, a simple acid immersion of samples cannot reflect the corrosion resistance of the mix as some mixes may inhibit the growth of bacteria instead of improving the chemical acid resistance. For example, Conshield, an additive to concrete mixes, was reported to be able to kill the sulfide-oxidizing bacteria (SOB) in the moisture film [62], but the chemical acid resistance was not improved. Thus, some researchers also tried to establish a test method that incorporates the microbial process occurred in sewer tunnels. For example, Mori et al. [83] and Sand et al. [84] built simulation chambers mimicking the sewer environment to test the biological corrosion of concrete. In these tests, specific conditions such as temperature, nutrients and humidity can be controlled. Furthermore, some researchers [12] mounted the concrete coupons in a real sewer 
tunnel to observe the physicochemical process of MIC. However, the duration is even longer for these tests incorporating the microbial process than the immersing method, normally in the magnitude of years. More research is needed to develop a test method that is not only time efficient but also able to simulate the real sewer condition as close as possible.

In addition to the lack of testing procedure, the second difficulty comes from the controversial results of acid resistance from various indicators. Acid resistance itself is not a parameter that can be characterized by a single test; instead, it needs to be assessed by many different parameters. Some parameters are mass loss [9,52,85-88], strength loss [89-91], dimensional changes [85,86,92,93], corrosion depth [86,94,95], hydrogen ion consumption, and mineralogical changes [95]. Despite the frequent use of these parameters in the assessment of the acid resistance of concrete, low correlation between these parameters was reported in these studies. For example, Vlasta et al. [96] measured the concrete $\mathrm{pH}$ and the concentrations of $\mathrm{Ca}^{2+}$ and $\mathrm{Si}^{4+}$ in immersion solution as the indicators of the deterioration. They conducted analytical and statistical methods to correlate these parameters, but they found low correlations of $\mathrm{Si} /$ concrete $\mathrm{pH}$ and $\mathrm{Ca} /$ concrete $\mathrm{pH}$ and an inverse correlation of $\mathrm{Si} /$ concrete $\mathrm{pH}$ for samples immersed in a $\mathrm{pH} 3$ sulfuric acid solution. In another study conducted by Chang et al. [92], a lack of correlation was also reported between mass change and strength change. This low correlation between assessing parameters may be due to the complex links between parameters and various processes. For example, among these parameters, mass loss that is the most commonly used one, is convenient to measure, and directly indicates the corrosion rate. However, the result of mass loss is greatly influenced by the sample density [97]. Strength is also not reliable because it is affected by three processes [97]: (1) corrosion reaction, which lowers the strength; (2) hydration reaction, which improves the strength; and (3) pore filling by corrosion products (e.g., gypsum), which improves the mechanical performance. Dimensional change and hydrogen ion consumption are not sensitive enough when acid used is at low concentrations. Thus, a combination of these indicators will be required to assess the acid resistance of concrete more accurately. However, there is very limited research focusing on this topic. The analytical and statistical models will be required to combine those assessing parameters.

\section{Drainage Design Standards}

A design standard would define requirements for planning, designing, constructing and maintaining drainage systems. Some standards [98] even include rehabilitating deteriorated sewer infrastructure. The review of microbially induced corrosion (MIC) fundamentals and rehabilitation showed that the progress of MIC is greatly related to the sewer design (hydraulic) and concrete mixture design. Proper design of drainage may be able to ease the MIC rate and extend the service life of concrete structures. This section is aiming to find out if the current municipal sewer design standards consider the MIC. Eight municipals design standards will be reviewed. Possible gaps will be identified, and recommendations will be made for further modifications to Edmonton's design standards. Building on the previous literature investigation of the MIC mechanism, design factors that can affect the MIC rate include flow velocity, concrete mix design, and retention time. The review will focus on these three aspects.

\subsection{Flow Velocity}

As mentioned in Section 2.1, flow velocity substantially affects the rate of MIC process. Eight municipal design standards were reviewed: those from Edmonton [99], London (Canada) [100], Hong Kong [98], Toronto [101], Saskatoon [102], Kamloops [103], Dallas [104], and Singapore [105]. Commonly, the flow velocity is calculated mainly to ensure that sewage is self-cleaning, and to minimize erosion and scouring. The effect of velocity on the progress of MIC is merely considered in the design standards. Table 9 lists the flow velocity specifications from various cities. Most cities use $0.6 \mathrm{~m} / \mathrm{s}$ as the minimum velocity to ensure particle suspension in the flow. However, there is a wide range of the maximum velocity. A velocity of $3.0 \mathrm{~m} / \mathrm{s}$ is adopted by most cities as the maximum value 
to prevent scouring and abrasion of the tunnel wall. This value is increased to $6 \mathrm{~m} / \mathrm{s}$ in Hong Kong when abrasion resistant pipe is used. Singapore and Kamloops use lower values of 2.4 and $2.5 \mathrm{~m} / \mathrm{s}$ respectively. London (Canada) sets $4.5 \mathrm{~m} / \mathrm{s}$ as the maximum allowable velocity.

A procedure to calculate velocity to prevent MIC was outlined in the United States (US) Environmental Protection Agency (EPA) design manual [15]. The change in flow velocity alters the dissolved oxygen (DO) level in sewage. Since the required DO level in sewage is related to temperature and the concentration of organic matter (or biochemical oxygen demand (BOD)), the EPA combined these two factors into effective BOD (EBOD) [15]. The required velocity to prevent MIC differs significantly depending on location. The EPA design manual [15] provides a detailed estimation of minimum pipe slope.

Table 9. Specifications for flow velocity.

\begin{tabular}{ccccl}
\hline City & $\begin{array}{c}\text { MIC/Odor } \\
\text { Issues }\end{array}$ & $\begin{array}{c}\text { Min Velocity } \\
(\mathbf{m} / \mathbf{s})\end{array}$ & $\begin{array}{c}\text { Max Velocity } \\
(\mathbf{m} / \mathbf{s})\end{array}$ & \multicolumn{1}{c}{ Comments } \\
\hline Edmonton & Yes & 0.6 & 3.0 & $\begin{array}{l}\text { 0.9-1.5 m/s (force main) } \\
\text { Prevents undue turbulence, minimizes odors } \\
\text { due to sulfide generation }\end{array}$ \\
\hline $\begin{array}{c}\text { London } \\
\text { (Canada) }\end{array}$ & Not applicable & 0.6 & 4.5 & Ensures self-cleansing and minimizes erosion \\
\hline Hong Kong & Yes [106] & 0.7 & 3.0 & $\begin{array}{l}\text { Max velocity can be relaxed to } 6 \mathrm{~m} / \mathrm{s} \text { for } \\
\text { abrasion-resistant pipe } \\
\text { Higher minimum velocities for larger sewers }\end{array}$ \\
\hline Toronto & Yes [16] & 0.6 & 3.0 & \begin{tabular}{l} 
Self-cleansing and minimizes erosion \\
\hline Saskatoon
\end{tabular} \\
Not applicable & 0.61 & 3.0 & $\begin{array}{l}\text { Reduces turbulence and scouring 1.0-1.6 m/s } \\
\text { (force main) }\end{array}$ \\
\hline Kamloops & Yes [107] & 0.6 & 2.5 & Self-cleansing and minimizes erosion \\
\hline Dallas & Yes [108] & 0.6 & 3.0 & Self-cleansing and minimizes erosion \\
\hline Singapore & Yes [109] & $0.8-0.9$ & 2.4 & Self-cleansing and minimizes erosion \\
\hline
\end{tabular}

\subsection{Retention Time}

As previously discussed, a long retention of sewage enhances the generation of $\mathrm{H}_{2} \mathrm{~S}$. Common causes for the long retention time are debris and sediment buildup, low flow velocity, and wastewater storage. Most city standards that were reviewed specified that sewers should be free of debris, and proper maintenance should be conducted to avoid grit and sediment buildup. The differences lie in the regulations concerning retention time in pump stations. Except for Edmonton and Hong Kong, the cities reviewed do not specify the shortest retention time for pump stations (see Table 10). In Edmonton, the maximum retention in a pump station is not to exceed $30 \mathrm{~min}$; the total retention in a wet well and the force main should be less than four hours. However, such short retention times mean that the storage capacity is very low, which does not meet the high demand of pump capacity in wet seasons. Consequently, the actual design of many pump stations in Edmonton did not follow this design specification (10.10.1.IV); instead, a higher value was often used. For example, at the Duggan Lift station near Southgate Centre, Edmonton, the retention time is designed to be as long as $24 \mathrm{~h}$. In this case, severe corrosion was observed at the discharge of the force main.

Table 10. Requirements of retention time in pump stations.

\begin{tabular}{cc}
\hline City & Retention Time \\
\hline Edmonton & 30 min in wet well \\
& $4 \mathrm{~h}$ in wet well and force main \\
\hline Hong Kong & $2 \mathrm{~h}$ \\
\hline
\end{tabular}




\subsection{Mixture Design in the Concrete Liner}

The material used in a liner is critical for extending the service life of concrete drainage structures under the MIC process. Most Canadian cities use Canadian Standards Association (CSA) standards for concrete mixture design and manufacturing, as listed in Table 11. In CSA standards, requirements for concrete are determined by the exposure level to the aggressive environment. Sewer concrete structures are subject to a class A exposure. For different classes of exposure, the CSA specifies various requirements for concrete. In an environment with more severe exposure, a lower water-to-cement ratio and higher strength are required. In class $\mathrm{A}-\mathrm{XL}$ and $\mathrm{A}-1$, concrete is expected to experience severe acid corrosion. Extra requirements for permeability are specified to extend the service life of a concrete structure subjected to class A-XL and A-1 exposure. For example, chloride penetrability should be $<1000$ coulombs within 91 days in class A-XL exposure [110]. In short, CSA standards have relatively comprehensive requirements for drainage structure concrete design.

Table 11. Canadian Standards Association (CSA) standards for concrete manufacture.

\begin{tabular}{ll}
\hline Construction & Standards \\
\hline Precast concrete pipe (reinforced) & CSA/CAN A257.2-14 [111] \\
Precast concrete pipe (non-reinforced) & CSA/CAN A257.1-14 [112] \\
Precast concrete segment & CSA A23.4-16 [113] \\
Grouting & CSA-A23.1-14 [110] and ASTM C404-11 [114] \\
Cement & CSA-A3000 [115] \\
Shotcrete & CSA A23.2-14 [110] \\
\hline
\end{tabular}

However, since acid corrosion on concrete is unavoidable, acid resistant materials are preferred for sewer construction when possible. There is still a lack of regulations for commonly used non-cement materials in sewer systems. These materials include polyvinyl chloride (PVC), resin, and epoxy. Based on the findings in this paper, it is recommended to include a list of approved materials in the COE standards. The list should specify the characteristics of the materials such as the bonding strength with a substrate, acid corrosion resistance, correspondent rehabilitation techniques, and costs.

\section{Concluding Remarks}

Microbially induced corrosion (MIC) has been recognized as a destructive process posing a severe threat to the sustainability of concrete in sewer tunnel. To address this, this paper conducted a narrative review of acid corrosion regarding corrosion mechanism, control methods, cement-based rehabilitation techniques and materials, and drainage design standards. The main findings are summarized in the following:

1. Three categories of main influencing factors were identified for the rate of MIC: hydraulic parameters, environmental factors, and concrete mixture design.

2. Many chemicals dosed to the sewage have been effective in reducing sulfide concentrations in sewage such as magnesium hydroxide, sodium hydroxide, iron salts, free nitrous acid (FNA), nitrate, oxygen, hydrogen peroxide, ozone, chlorine, and permanganate.

3. A proper sewer tunnel design is an efficient and cost-efficient method to control MIC. It is recommended to consider MIC during the hydraulic design phase. However, the current $\mathrm{COE}$ standards do not include any related regulations.

4. All hydraulic-cement concretes, regardless of the composition, are unable to withstand for long in an acid with a pH below 3 . However, improving the concrete mixture design is still a viable method for controlling MIC rate because it changes the rate of the corrosion reaction process.

5. Cement-based rehabilitation methods can be used in severely deteriorated tunnels to provide structural restoration. However, supplementary measures (e.g., coating and chemical dosing) should be taken to prevent future corrosion, due to the alkaline nature of the cement-based material. 
6. No available testing standard was found that guides the acid resistance test of cement-based material at present.

7. There is a lack of regulations on commonly used non-cement materials in COE standards. It is recommended to include a list of approved materials in the COE standards specifying the characteristics of the materials such as the bonding strength with a substrate, acid corrosion resistance, correspondent rehabilitation techniques, and costs.

Acknowledgments: This paper is based on the research project "Sustainability of Concrete for Drainage Structure" under the Sustainability Scholars' Program between the University of Alberta and the City of Edmonton. The authors are thankful for this program for providing funding to this project. In addition, continued financial support from the Natural Sciences and Engineering Research Council (NSERC), Canada, is gratefully acknowledged.

Author Contributions: Linping Wu collected relevant literature and wrote the paper; Chaoshi Hu provided site visits, industry supervision, and technical guide in the Sustainability Scholars' Program; and Wei Victor Liu was the academic supervisor and co-wrote the paper.

Conflicts of Interest: The authors declare no conflict of interest.

\section{References}

1. U.S. Environmental Protection Agency. Hydrogen Sulfide Corrosion in Wastewater Collection and Treatment Systems; U.S. Environmental Protection Agency: Washington, DC, USA, 1991; p. 59.

2. Apgar, D.; Witherspoon, J. Minimization of Odors and Corrosion in Collection Systems; Water Environment Research Foundation: Alexandria, VA, USA, 2008.

3. Brongers, M.; Virmani, P.; Payer, J. Drinking Water and Sewer Systems in Corrosion Costs and Preventative Strategies in the United States; United States Department of Transportation Federal Highway Administration: Washington, DC, USA, 2002.

4. Neville, A. Chloride attack of reinforced concrete: An overview. Mater. Struct. 1995, 28, 63-70. [CrossRef]

5. Emmanuel, K.A.; Sami, H.R. Response of concrete to sulfuric acid attack. Mater. J. 1988, 85, 481-488.

6. Stolte, E. Major Edmonton Sewer Trunk Line Hanging on by "Ribs and Lagging". Available online: http:/ / edmontonjournal.com/news/local-news/major-edmonton-sewer-trunk-line-hanging-on-byribs-and-lagging (accessed on 31 August 2017).

7. Chris Ward. City of Edmonton. In 2016-2018 Business Plan; Utility Services: City of Edmonton, AB, Canada, 2016; p. 19. Available online: https://www.edmonton.ca/city_government/documents/Utility_Services_ Business_Plan_2016-2018.pdf (accessed on 31 August 2017).

8. Jiang, G.; Keller, J.; Bond, P.L.; Yuan, Z. Predicting concrete corrosion of sewers using artificial neural network. Water Res. 2016, 92, 52-60. [CrossRef] [PubMed]

9. Alexander, M.; Fourie, C. Performance of sewer pipe concrete mixtures with portland and calcium aluminate cements subject to mineral and biogenic acid attack. Mater. Struct. 2011, 44, 313-330. [CrossRef]

10. House, M.W. Using Biological and Physico-Chemical Test Methods to Assess the Role of Concrete Mixture Design in Resistance to Microbially Induced Corrosion; Purdue University: West Lafayette, IN, USA, 2013.

11. Reardon, E.J. An ion interaction model for the determination of chemical equilibria in cement/water systems. Cem. Concr. Res. 1990, 20, 175-192. [CrossRef]

12. Wells, T.; Melchers, R.E. An observation-based model for corrosion of concrete sewers under aggressive conditions. Cem. Concr. Res. 2014, 61-62, 1-10. [CrossRef]

13. Æsøy, A.; Østerhus, S.W.; Bentzen, G. Controlled treatment with nitrate in sewers to prevent concrete corrosion. Water Sci. Technol. 2002, 2, 137-144.

14. Okun, D.A.; Wang, L.K.; Shammas, N.K. Water Supply and Distribution and Wastewater Collection; John Wiley and Sons: Hoboken, NJ, USA, 2010.

15. Bowker, R.P.; Smith, J.M. Odor and Corrosion Control in Sanitary Sewerage Systems and Treatment Plants; U.S. Environmental Protection Agency: Washington, DC, USA, 1985.

16. Hewayde, E.H. Investigation on Degradation of Concrete Sewer Pipes by Sulfuric Acid Attack. Ph.D. Thesis, The University of Western Ontario, London, ON, Canada, 2005.

17. Firer, D.; Friedler, E.; Lahav, O. Control of sulfide in sewer systems by dosage of iron salts: Comparison between theoretical and experimental results, and practical implications. Sci. Total Environ. 2008, 392, 145-156. [CrossRef] [PubMed] 
18. House, M.W.; Weiss, W.J. Review of microbially induced corrosion and comments on needs related to testing procedures. In Proceedings of the 4th International Conference on the Durability of Concrete Structures, ICDCS 2014, West Lafayette, IN, USA, 24-26 July 2014; Purdue University: West Lafayette, IN, USA, 2014; pp. 94-103.

19. Wells, T.; Melchers, R.E.; Bond, P. Factors involved in the long term corrosion of concrete sewers. In Proceedings of the Australasian Corrosion Association Proceedings of Corrosion and Prevention, Coffs Harbour, Australia, 15-18 November 2009.

20. Vollertsen, J.; Nielsen, A.H.; Jensen, H.S.; Wium-Andersen, T.; Hvitved-Jacobsen, T. Corrosion of concrete sewers-The kinetics of hydrogen sulfide oxidation. Sci. Total Environ. 2008, 394, 162-170. [CrossRef] [PubMed]

21. Sun, X. Improving the Understanding of Concrete Sewer Corrosion through Investigations of the Gaseous Hydrogen Sulfide Uptake and Transformation Processes in the Corrosion Laye; The University of Queensland: Brisbane, Queensland, 2015.

22. American Concrete Institute (ACI) Committee 201. Guide to Durable Concrete; ACI Committee: Farmington Hills, MI, USA, 2001.

23. Portland Cement Association. Concrete Information: Types and Causes of Concrete Deterioration; PCA R\&D Serial; Portland Cement Association: Skokie, IL, USA, 2002. Available online: http://www.cement.org/docs/defaultsource/fc_concrete_technology/durability / is536-types-and-causes-of-concrete-deterioration.pdf?sfvrsn=4 (accessed on 15 July 2017).

24. Huseyin, S.; Mohammed, M.; Mohammed, S.; Ibrabimm, A. Case study of deterioration of concrete in sewage environment in an Arabian Gulf country. Durab. Build. Mater. 1987, 5, 145-154.

25. Joseph, A.P.; Keller, J.; Bustamante, H.; Bond, P.L. Surface neutralization and h2s oxidation at early stages of sewer corrosion: Influence of temperature, relative humidity and h2s concentration. Water Res. 2012, 46, 4235-4245. [CrossRef] [PubMed]

26. Sublette, K.L.; Kolhatkar, R.; Raterman, K. Technological aspects of the microbial treatment of sulfide-rich wastewaters: A case study. Biodegradation 1998, 9, 259-271. [CrossRef] [PubMed]

27. Rootsey, R.; Melchers, R.; Stuetz, R.; Keller, J.; Yuan, Z. Taking control of odours and corrosion in sewers. In Proceedings of the Australia's National Water Conference and Exhibition (OzWater 2012), Sydney, Australia, 8-10 May 2012; pp. 8-10.

28. Islander, R.L.; Devinny, J.S.; Mansfeld, F.; Postyn, A.; Shih, H. Microbial ecology of crown corrosion in sewers. J. Environ. Eng. 1991, 117, 751-770. [CrossRef]

29. Wells, T.; Melchers, R.; Joseph, A.; Bond, P.; Vitanage, D.; Bustamante, H.; De Grazia, J.; Kuen, T.; Nazimek, J.; Evans, T. A Collaborative Investigation of the Microbial Corrosion of Concrete Sewer Pipe in Australia; Australian Water Association: St Leonards, Australia, 2012.

30. Idriss, A.; Negi, S.; Jofriet, J.; Hayward, G. Effect of hydrogen sulphide emissions on cement mortar specimens. Can. Biosyst. Eng. 2001, 43, 523-528.

31. Parande, A.; Ramsamy, P.; Ethirajan, S.; Rao, C.; Palanisamy, N. Deterioration of reinforced concrete in sewer environments. Proc. Inst. Civ. Eng.-Munic. Eng. 2006, 159, 11-20. [CrossRef]

32. Jiang, G.; Wightman, E.; Donose, B.C.; Yuan, Z.; Bond, P.L.; Keller, J. The role of iron in sulfide induced corrosion of sewer concrete. Water Res. 2014, 49, 166-174. [CrossRef] [PubMed]

33. Hewayde, E.; Nehdi, M.; Allouche, E.; Nakhla, G. Effect of mixture design parameters and wetting-drying cycles on resistance of concrete to sulfuric acid attack. J. Mater. Civ. Eng. 2007, 19, 155-163. [CrossRef]

34. Ganigue, R.; Gutierrez, O.; Rootsey, R.; Yuan, Z. Chemical dosing for sulfide control in Australia: An industry survey. Water Res. 2011, 45, 6564-6574. [CrossRef] [PubMed]

35. Sun, J.; Pikaar, I.; Sharma, K.R.; Keller, J.; Yuan, Z. Feasibility of sulfide control in sewers by reuse of iron rich drinking water treatment sludge. Water Res. 2015, 71, 150-159. [CrossRef] [PubMed]

36. Zhang, L.; Keller, J.; Yuan, Z. Inhibition of sulfate-reducing and methanogenic activities of anaerobic sewer biofilms by ferric iron dosing. Water Res. 2009, 43, 4123-4132. [CrossRef] [PubMed]

37. Jiang, G.; Gutierrez, O.; Yuan, Z. The strong biocidal effect of free nitrous acid on anaerobic sewer biofilms. Water Res. 2011, 45, 3735-3743. [CrossRef] [PubMed]

38. Jiang, G.; Gutierrez, O.; Sharma, K.R.; Keller, J.; Yuan, Z. Optimization of intermittent, simultaneous dosage of nitrite and hydrochloric acid to control sulfide and methane productions in sewers. Water Res. 2011, 45, 6163-6172. [CrossRef] [PubMed] 
39. Mohanakrishnan, J.; Gutierrez, O.; Meyer, R.L.; Yuan, Z. Nitrite effectively inhibits sulfide and methane production in a laboratory scale sewer reactor. Water Res. 2008, 42, 3961-3971. [CrossRef] [PubMed]

40. Mohanakrishnan, J.; Gutierrez, O.; Sharma, K.R.; Guisasola, A.; Werner, U.; Meyer, R.L.; Keller, J.; Yuan, Z. Impact of nitrate addition on biofilm properties and activities in rising main sewers. Water Res. 2009, 43, 4225-4237. [CrossRef] [PubMed]

41. Gutierrez, O.; Mohanakrishnan, J.; Sharma, K.R.; Meyer, R.L.; Keller, J.; Yuan, Z. Evaluation of oxygen injection as a means of controlling sulfide production in a sewer system. Water Res. 2008, 42, 4549-4561. [CrossRef] [PubMed]

42. Cadena, F.; Peters, R.W. Evaluation of chemical oxidizers for hydrogen sulfide control. Water Pollut. Control Fed. 1988, 60, 1259-1263.

43. Subcommittee on Paints and Protective Coatings. Paints and Protective Coatings for Wastewater Treatment Facilities; Volume Manual of Practice No. 17; Water Pollution Control Federation: Washington, DC, USA, 1969.

44. Pomeroy, R.; Bowlus, F.D. Progress report on sulfide control research. Sew. Works J. 1946, 18, 597-640.

45. USP Technoligies. Force Main System Sulfide Control with Hydrogen Peroxide. Available online: http:/ / www. h2o2.com/municipal-applications / wastewater-treatment.aspx?pid=128\& (accessed on 29 May 2017).

46. Churchill, P.; Elmer, D. Hydrogen sulfide odor control in wastewater collection systems. J. N. Engl. Water Environ. Assoc. 1999, 33, 57-63.

47. Clidence, D.; Shissler, D. Elimination of odor and hydrogen sulfide gas by superoxygenation of the bluebird force main in Laguna beach, California. Proc. Water Environ. Fed. 2008, 2008, 815-825. [CrossRef]

48. Hossain, M.M.; Karim, M.R.; Hasan, M.; Hossain, M.K.; Zain, M.F.M. Durability of mortar and concrete made up of pozzolans as a partial replacement of cement: A review. Constr. Build. Mater. 2016, 116, 128-140. [CrossRef]

49. Sabir, B.B.; Wild, S.; Bai, J. Metakaolin and calcined clays as pozzolans for concrete: A review. Cem. Concr. Compos. 2001, 23, 441-454. [CrossRef]

50. Mehta, P.K. Properties of blended cements made from rice husk ash. J. Am. Concr. Inst. 1977, 74, 440-442.

51. Torii, K.; Kawamura, M. Effects of fly ash and silica fume on the resistance of mortar to sulfuric acid and sulfate attack. Cem. Concr. Res. 1994, 24, 361-370. [CrossRef]

52. Roy, D.M.; Arjunan, P.; Silsbee, M.R. Effect of silica fume, metakaolin, and low-calcium fly ash on chemical resistance of concrete. Cem. Concr. Res. 2001, 31, 1809-1813. [CrossRef]

53. Duan, P.; Shui, Z.; Chen, W.; Shen, C. Effects of metakaolin, silica fume and slag on pore structure, interfacial transition zone and compressive strength of concrete. Constr. Build. Mater. 2013, 44, 1-6. [CrossRef]

54. Dunster, A.M.; Parsonage, J.R.; Thomas, M.J.K. The pozzolanic reaction of metakaolinite and its effects on portland cement hydration. J. Mater. Sci. 1993, 28, 1345-1350. [CrossRef]

55. Gruyaert, E.; Van den Heede, P.; Maes, M.; De Belie, N. Investigation of the influence of blast-furnace slag on the resistance of concrete against organic acid or sulphate attack by means of accelerated degradation tests. Cem. Concr. Res. 2012, 42, 173-185. [CrossRef]

56. Monteny, J.; De Belie, N.; Taerwe, L. Resistance of different types of concrete mixtures to sulfuric acid. Mater. Struct. 2003, 36, 242-249. [CrossRef]

57. Chatveera, B.; Lertwattanaruk, P.; Makul, N. Effect of sludge water from ready-mixed concrete plant on properties and durability of concrete. Cem. Concr. Compos. 2006, 28, 441-450. [CrossRef]

58. Senhadji, Y.; Escadeillas, G.; Mouli, M.; Khelafi, H.; Benosman. Influence of natural pozzolan, silica fume and limestone fine on strength, acid resistance and microstructure of mortar. Powder Technol. 2014, 254, 314-323. [CrossRef]

59. Kannan, V.; Ganesan, K. Chloride and chemical resistance of self compacting concrete containing rice husk ash and metakaolin. Constr. Build. Mater. 2014, 51, 225-234. [CrossRef]

60. Tamimi, A. High-performance concrete mix for an optimum protection in acidic conditions. Mater. Struct. 1997, 30, 188-191. [CrossRef]

61. Hewayde, E.; Nehdi, M.L.; Allouche, E.; Nakhla, G. Using concrete admixtures for sulphuric acid resistance. Proc. Inst. Civ. Eng. Constr. Mater. 2007, 160, 25-35. [CrossRef]

62. Conshield Inc. Technical Bulletin-Conshield. Available online: http://www.conshield.com/ConShield/ TheScienceofConShield/tabid/89/Default.aspx (accessed on 25 July 2017).

63. Park, S.-K.; Kim, J.-H.J.; Nam, J.-W.; Phan, H.D.; Kim, J.-K. Development of anti-fungal mortar and concrete using zeolite and zeocarbon microcapsules. Cem. Concr. Compos. 2009, 31, 447-453. [CrossRef] 
64. Freed, W.W. Reinforced Concrete Containing Antimicrobial-Enhanced Fibers. Google Patents WO 1995006086 A3, 2000.

65. Emmel, T.; Brill, H.; Sand, W.; Bock, E. Screening for biocides to inhibit biogenic sulphuric acid corrosion in sewage pipelines. In Biodeterioration 7; Houghton, D.R., Smith, R.N., Eggins, H.O.W., Eds.; Springer: Dordrecht, The Netherlands, 1988; pp. 118-122.

66. Valix, M.; Zamri, D.; Mineyama, H.; Cheung, W.H.; Shi, J.; Bustamante, H. Microbiologically induced corrosion of concrete and protective coatings in gravity sewers. Chin. J. Chem. Eng. 2012, 20, 433-438. [CrossRef]

67. Sun, X.; Jiang, G.; Chiu, T.H.; Zhou, M.; Keller, J.; Bond, P.L. Effects of surface washing on the mitigation of concrete corrosion under sewer conditions. Cem. Concr. Compos. 2016, 68, 88-95. [CrossRef]

68. Water Environment Federation. Existing Sewer Evaluation and Rehabilitation; WEF Manual of Practice 3rd ed.; WEF Press-Water Environment Federation: Alexandria, VA, USA, 2009.

69. Morrison, R.; Sangster, T.; Downey, D.; Matthews, J.; Condit, W.; Sinha, S.; Maniar, S.; Sterling, R. State of Technology for Rehabilitation of Water Distribution Systems; EPA/600/R-13/036 2013; United States Environmental Protection Agency: Washington, DC, USA, 2013.

70. American Concrete Institute (ACI) Committee 506. Guide to Shotcrete; ACI Committee: Farmington Hills, MI, USA, 2016. Available online: https://www.concrete.org/store/productdetail.aspx?ItemID=50616\& Language=English (accessed on 17 June 2017).

71. Schrader, E.K.; Kaden, R.A. Durability of shotcrete. Spec. Publ. 1987, 100, 1071-1102. Available online: https://www.concrete.org/publications/internationalconcreteabstractsportal/m/details/id/3744 (accessed on 21 June 2017).

72. McAlpine, G.; Anderson, B. Structural rehabilitation of cast-in-place concrete sewers. In Pipelines 2005: Optimizing Pipeline Design, Operations, and Maintenance in Today's Economy; American Society of Civil Engineers (ASCE): Reston, VA, USA, 2005; pp. 510-522. Available online: https://ascelibrary.org/doi/pdf/ 10.1061/40800\%28180\%2940 (accessed on 7 February 2018).

73. Stein, D.; Stein, R. Rehabilitation and Maintenance of Drains and Sewers (e-book). UNITRACC.com. 2004. Available online: https:/ / www.unitracc.com/know-how/fachbuecher/rehabilitation-and-maintenanceof-drains-and-sewers (accessed on 7 February 2018).

74. Norman, E. Manhole rehabilitation: Delivering on the design with proper installation practices and related quality assurance testing. In Proceedings of the North American Society for Trenchless Technology (NASTT) NASTT's 2016 No-Dig Show, Dallas, TX, USA, 20-24 March 2016; p. 9.

75. Koehn, K.W. Methods and Benefits of Spincasting Cements on Corrugated Metal Pipes; C. K. Masonry Co. Inc.: Nashville, TN, USA, 1994; p. 4.

76. Dinakar, P.; Babu, K.G.; Santhanam, M. Durability properties of high volume fly ash self compacting concretes. Cem. Concr. Compos. 2008, 30, 880-886. [CrossRef]

77. Pavel, R.; Jiří, T. Resistance of concrete with metakaolin addition to acid environment. Key Eng. Mater. 2016, 677, 144-149.

78. Durning, T.A.; Hicks, M.C. Using microsilica to increase concrete's resistance to aggressive chemicals. Concr. Int. 1991, 13, 42-48.

79. Ekolu, S.O.; Diop, S.; Azene, F.; Mkhize, N. Disintegration of concrete construction induced by acid mine drainage attack. J. S. Afr. Inst. Civ. Eng. 2016, 58, 34-42. [CrossRef]

80. Shetti, A.P.; Das, B.B. Acid, alkali and chloride resistance of early age cured silica fume concrete. In Advances in Structural Engineering: Materials; Springer: New Delhi, India, 2015; Volume 3, pp. 1849-1862.

81. Chindaprasirt, P.; Homwuttiwong, S.; Sirivivatnanon, V. Influence of fly ash fineness on strength, drying shrinkage and sulfate resistance of blended cement mortar. Cem. Concr. Res. 2004, 34, 1087-1092. [CrossRef]

82. Newman, J.; Choo, B.S. Advanced Concrete Technology 3: Processes; Butterworth-Heinemann: Oxford, UK, 2003.

83. Mori, T.; Nonaka, T.; Tazaki, K.; Koga, M.; Hikosaka, Y.; Noda, S. Interactions of nutrients, moisture and pH on microbial corrosion of concrete sewer pipes. Water Res. 1992, 26, 29-37. [CrossRef]

84. Sand, W. Biotest system for rapid evaluation of concrete resitance to sulfur-oxidizing bacteria. Mater. Perform. 1987, 26, 14-17.

85. Shing, C.K.; Wu, C.L.; Chen, J.W.; Yuen, C.S.; Tsui, R.Y. A review on protection of concrete for sewage installations and an accelerated test on protection systems. HKIE Trans. 2012, 19, 8-16.

86. Koenig, A.; Dehn, F. Main considerations for the determination and evaluation of the acid resistance of cementitious materials. Mater. Struct. 2016, 49, 1693-1703. [CrossRef] 
87. Breit, W. Säurewiderstand von beton-acid resistance of concrete. Beton 2002, 52, 505-510.

88. Fernando, P.-T.; Said, J. Resistance to acid attack, abrasion and leaching behavior of alkali-activated mine waste binders. Mater. Struct. 2011, 44, 487-498. [CrossRef]

89. Aydın, S.; Yazıcı, H.; Yiğiter, H.; Baradan, B. Sulfuric acid resistance of high-volume fly ash concrete. Build. Environ. 2007, 42,717-721. [CrossRef]

90. Ariffin, M.; Bhutta, M.; Hussin, M.; Tahir, M.M.; Aziah, N. Sulfuric acid resistance of blended ash geopolymer concrete. Constr. Build. Mater. 2013, 43, 80-86. [CrossRef]

91. Jerlin Regin, J.; Vincent, P.; Ganapathy, C. Effect of mineral admixtures on mechanical properties and chemical resistance of lightweight coconut shell concrete. Arab. J. Sci. Eng. 2017, 42, 957-971. [CrossRef]

92. Chang, Z.T.; Song, X.J.; Munn, R.; Marosszeky, M. Using limestone aggregates and different cements for enhancing resistance of concrete to sulphuric acid attack. Cem. Concr. Res. 2005, 35, 1486-1494. [CrossRef]

93. De Belie, N.; Monteny, J.; Taerwe, L. Apparatus for accelerated degradation testing of concrete specimens. Mater. Struct. 2002, 35, 427-433. [CrossRef]

94. Macías, A.; Goni, S.; Madrid, J. Limitations of köch-steinegger test to evaluate the durability of cement pastes in acid medium. Cem. Concr. Res. 1999, 29, 2005-2009. [CrossRef]

95. Yuan, H.; Dangla, P.; Chatellier, P.; Chaussadent, T. Degradation modelling of concrete submitted to sulfuric acid attack. Cem. Concr. Res. 2013, 53, 267-277. [CrossRef]

96. Ondrejka Harbulakova, V.; Estokova, A.; Kovalcikova, M. Correlation analysis between different types of corrosion of concrete containing sulfate resisting cement. Environments 2017, 4, 44. [CrossRef]

97. Alexander, M.; Bertron, A.; De Belie, N. Performance of Cement-Based Materials in Aggressive Aqueous Environments; Springer: New York, NY, USA, 2013; Volume 10.

98. Government of the Hong Kong-Special Administrative Region. Sewerage manual. In Key Planning Issues and Gravity Collection System; Drainage Services Department: Hong Kong, China, 2013.

99. City of Edmonton. In Design and Construction Standards; Volume 3-Drainage; Edmonton, AB, Canada, 2015. Available online: https://www.edmonton.ca/city_government/documents/Volume_3_Drainage_.pdf (accessed on 12 June 2017).

100. City of London (Canada). In Design Specifications \& Requirements Manual; City of London, 2015. Available online: http:/ / www.london.ca/business/Resources/Consultant-Resources/Documents /Specs\%20and\% 20Reqs\%202015/DSRM-2015-EntireDoc.pdf (accessed on 12 June 2017).

101. City of Toronto. In Design Criteria for Sewers and Watermains. Standards, Policies and Quality Assurance, District Engineering Services; 2009. Available online: https:/ /www.toronto.ca/wp-content/uploads/2017/11/9753ecs-specs-dcm-Toronto_Sewer_and_Watermain_Manual_March2014.pdf (accessed on 12 June 2017).

102. City of Saskatoon. In Design and Development Standards Manual in Section Five-Sanitary Sewer Collection System, City of Saskatoon; 2017. Available online: https://www.saskatoon.ca/sites/default/files/ documents / transportation-utilities / construction-design/new-neighbourhood-design/5._2017_section_ five_-_sanitary_sewer_collection_system.pdf (accessed on 12 June 2017).

103. City of Kamloops. In Design Criteria Manual; Development and Engineering Services Department-Engineering Development Section: Kamloops, BC, Canada, 2012. Available online: https://www.kamloops.ca/sites/ default/ files/docs/city-services/12-designcriteriamanual.pdf (accessed on 12 June 2017).

104. City of Dallas. In Water and Wastewater Procedures and Design Manual; Dallas Water Utilities, 2015. Available online: http:/ / dallascityhall.com/departments/waterutilities/DCH\%20Documents/pdf/Water_ and_Wastewater_Procedures_and_Design_Manual_October_2015.pdf (accessed on 12 June 2017).

105. Singapore. In Code of Practice in Sewerage and Sanitary Works Water, Reclamation (Network) Department; 2004. Available online: https://www.scribd.com/document/39703354/Code-of-Practice-on-Sewerage-andSanitary-Works (accessed on 12 June 2017).

106. Larsen, T.A.; Udert, K.M.; Lienert, J. Source Separation and Decentralization for Wastewater Management. Iwa Publishing: London, UK, 2013.

107. Klassen, A. Sewer-System Fix Is Costly. Available online: http://www.kamloopsthisweek.com/sewersystem-fix-is-costly/ (accessed on 21 June 2017).

108. Wodetzki, B.; Kaakaty, C. Iron-the optimal solution for odor and corrosion. Proc. Water Environ. Fed. 2013, 2013, 5467-5472. [CrossRef]

109. Jenkins, S.H. Eighth International Conference on Water Pollution Research: Proceedings of the 8th International Conference, Sydney, Australia, 1976; Elsevier: Amsterdam, The Netherlands, 2013. 
110. Canadian Standards Association (CSA). A23.1-14/a23.2-14-Concrete Materials and Methods of Concrete Construction/Test Methods and Standard Practices for Concrete; CSA: Mississauga, ON, Canada, 2014.

111. Canadian Standards Association (CSA). A257.2-14-Reinforced Circular Concrete Culvert, Storm Drain, Sewer Pipe, and Fittings; CSA: Mississauga, ON, Canada, 2014.

112. Canadian Standards Association (CSA). A257.1-14-Non-Reinforced Circular Concrete Culvert, Storm Drain, Sewer Pipe, and Fittings; CSA: Mississauga, ON, Canada, 2014.

113. Canadian Standards Association (CSA). A23.4-16-Precast Concrete-Materials and Construction; CSA: Mississauga, ON, Canada, 2000.

114. American Society for Testing Materials (ASTM). Astm c404-11 Standard Specification for Aggregates for Masonry Grout; ASTM International: West Conshohocken, PA, USA, 2011.

115. Canadian Standards Association (CSA). A3000-13-Cementitious Materials Compendium; CSA: Mississauga, ON, Canada, 2013.

(C) (2)

(C) 2018 by the authors. Licensee MDPI, Basel, Switzerland. This article is an open access article distributed under the terms and conditions of the Creative Commons Attribution (CC BY) license (http://creativecommons.org/licenses/by/4.0/). 